\title{
Three new species of leaflitter frogs from the upper Amazon forests: cryptic diversity within Pristimantis "ockendeni” (Anura: Strabomantidae) in Ecuador
}

\author{
KATHRYN R. ELMER ${ }^{1,2 *} \&$ DAVID C. CANNATELLA ${ }^{3}$ \\ ${ }^{1}$ Department of Biology, Queen's University, Kingston ON K7L 3N6 Canada. \\ ${ }^{2}$ Lehrstuhl für Zoologie und Evolutionsbiologie, Department of Biology, University of Konstanz, Universitätstraße 10, 78457 Kon- \\ stanz, Germany. E-mail: kathryn.elmer@uni-konstanz.de \\ ${ }^{3}$ Section of Integrative Biology and Texas Memorial Museum, The University of Texas, Austin, TX 78712, USA. E-mail: cat- \\ fish@mail.utexas.edu \\ * corresponding author
}

\begin{abstract}
We describe three new species of Pristimantis leaflitter frogs from the upper Amazon basin of Ecuador: Pristimantis achuar, Pristimantis altamnis, and Pristimantis kichwarum. Each of these new species was previously considered to be part of a single species, formerly known as Eleutherodactylus ockendeni (Boulenger) morph B. However, analysis of DNA sequences together with examination of the morphology of more than 600 specimens from Ecuador reveals that multiple species were confused under the same name. The morphological differences among the three new species are subtle but consistent: presence or absence of a black canthal stripe and/or supratympanic ridge, snout-vent length, and ventral colouration. The three species are generally allopatric and geographically restricted, although at some localities two of the species occur sympatrically.
\end{abstract}

\section{Resumen}

Describimos tres especies nuevas de ranas del sotobosque de la cuenca Amazónica Ecuatoriana: Pristimantis achuar, Pristimantis altamnis y Pristimantis kichwarum. Estas especies fueron consideradas antes como una sola especie bajo el nombre Eleutherodactylus ockendeni (Boulenger) morfo B. Sin embargo, el análisis de secuencias de ADN y la examinación de la morfología de más que 600 especímenes Ecuatorianos indican que en realidad existen tres especies. Sus diferencias morfológicas son sutiles pero constantes: presencia o ausencia de una raya cantal negra y/o de un pliegue supratimpánico y su coloración ventral. Las tres especies tienen distribuciones alopátricas y distintas aunque en algunas localidades se puede encontrar dos de las tres especies juntas.

Key words Anura; new species; terrestrial frog; South America; Pristimantis achuar; Pristimantis altamnis; Pristimantis kichwarum

\section{Introduction}

The upper Amazon region, particularly of Ecuador, is distinguished for having a great number of species of Pristimantis frogs (Lynch 1980; Flores \& Vigle 1994; Zimmerman \& Simberloff 1996; Coloma 2007). Though the upper Amazon rainforest of Ecuador is considered one of the most intensively studied areas in South America (Heyer 1988; Flores \& Vigle 1994), the region is nonetheless vast, often scientifically unexplored, and biologically and topographically complex: unidentified specimens, new species, and range extensions of Pristimantis frogs are frequently discovered (recent examples include Cisneros-Heredia 2005, 2006; Elmer 2004; Guayasamín et al. 2006; KRE unpubl. data, G. Vigle unpubl. data). 
The name Pristimantis ockendeni (previously, Eleutherodactylus ockendeni) has been generally applied to a leaflitter frog found in primary and secondary forests throughout the upper Amazon basin from southern Peru to Colombia (Boulenger 1912; Lynch 1974, 1980; Pearman 1997; Doan \& Arizábal Arriaga 2002; Padial et al. 2004; Elmer et al. 2007a,b). In some areas, such as the upper Napo and upper Arajuno river drainages, it is one of the most common Pristimantis, though this abundance is not equal across its Ecuadorean range (Pearman 1997; KRE unpubl. data). Recent genetic analyses of $P$. "ockendeni" collected from throughout eastern Ecuador demonstrated minimally three highly distinct genetic lineages, sufficiently divergent to suggest they are different species (Elmer et al. 2007b). We conducted an a posteriori examination of more than 600 specimens (from Elmer et al. 2007a,b and additional museum specimens) and found previously unrecognized subtle but highly consistent morphological differences among the three genetic lineages. We here describe them as new species, while also clarifying some taxonomic issues surrounding $P$. ockendeni and species synonymized with it.

\section{Materials and Methods}

Specimens were fixed in 10\% formalin and stored in 70\% alcohol. Diagnoses and descriptions generally follow Lynch (1974) and Duellman \& Pramuk (1999). We examined alcohol-preserved specimens from the herpetology collection (as of Feb. 2007) at the Museo de Zoología of the Pontificia Universidad Católica del Ecuador (QCAZ). Colour photographs of a syntype of Hylodes ockendeni (British Museum of Natural History, BMNH 1947.2.16.89) (provided by J.M. Padial) and the holotype of Syrrhophus calcaratus in the Naturhistoriska Rijkmuseet, Stockholm, NRM 1921 (provided by E. Åhlander) were examined.

Measurements in Diagnosis and Description refer to all or a subset of the paratype series including the holotype. Measurements in Table 2 are of paratypes and a subset of examined QCAZ adult specimens. Paratype specimens were selected on the criteria of being from a single locality with relatively large sample sizes, collected by KRE, and many having mtDNA sequence publicly available. Morphological measurements were taken with digital callipers for all or a subset of: snout-vent length (SVL), tibia length, foot length, head width, head length, interorbital distance (IOD), eye to nostril distance (END), eye diameter, tympanum diameter, femur length, forelimb length, and internarial distance. Sex and maturity were determined by the presence of ovarian eggs or convoluted oviducts in females, the presence of vocal slits and/or testes in males, or by the collection of pairs in amplexus. The numbered list of characters in the Diagnosis follows Duellman \& Pramuk (1999). We used a Wild Heerbrugg M3B dissecting scope for fine detail observations. Colour patterns in life were taken from KRE's field notes. Details of DNA sequencing can be found in Elmer et al. (2007b). DNA sequences were compiled in MacClade v4 (Maddison and Maddison 2003), redundant DNA sequences were determined in Collapse v1.2 (Posada 2004) and genetic distances were calculated in PAUP* beta v4 (Swofford 2003).

Heinicke et al. (2007) and Hedges et al. (2008) use the genus Pristimantis for a large clade of South American species. We feel that this causes regrettable instability to the taxonomy of eleutherodactyline frogs. Following the preference of the first author, we describe these new species under the genus Pristimantis. Similarly, the placement of this genus in the family Strabomantidae is followed. However, the second author (DCC) prefers different taxonomic concepts for both taxa that require fewer changes in names; these concepts will be elaborated elsewhere. 


\section{Species descriptions}

\section{Pristimantis achuar sp. nov.}

Figures 1-4, 6 .

Holotype. QCAZ 25463 (field number SC11438) an adult female collected at Kapawi Jungle Lodge, Pastaza

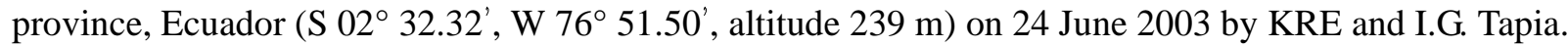

Paratypes. (25 specimens: 10 males, 10 females, 5 juveniles) QCAZ 25454, 25456-63, 25490-92, 2552330, 25532, 25534, 25538, 25545, 25547, and tissues were collected at Kapawi Jungle Lodge (type locality) from 24-27 June 2003 by KRE and I.G. Tapia.

Referred specimen. QCAZ 25273 collected from Auca 14 Rd near Dayuma, Orellana province, Ecuador (S $00^{\circ} 41.85^{\prime}$, W $76^{\circ} 43.79^{\prime}$, altitude 255 m) on 20 March 2003 by KRE, P. Menéndez-Guerrero, and S. Padilla.

\section{Etymology}

This species is named for the Achuar indigenous nation of the upper Amazon basin, who are ardent protectors of their biodiversity and generously granted permission to KRE to sample frogs from their land at Kapawi Lodge. The epithet is a noun in apposition.

\section{Diagnosis}

(1) skin of dorsum smooth to finely shagreened with W-shaped occipital-scapular ridges; skin of venter areolate; discoidal folds absent; dorsolateral folds absent; (2) tympanum distinct, tympanic annulus barely or slightly discernable, approximately one-third eye width; (3) snout subacuminate (weakly pointed) in dorsal view, rounded in lateral profile, canthus rostralis from anterior corner of eye to nostril straight in profile, concave in dorsal view, sharply angled in cross-section; (4) upper eyelid bearing one or two low tubercles in some individuals; (5) odontophores weakly raised, oval, oblique; (6) males with moderately sized vocal slits, nuptial pads absent; (7) first finger shorter than second; all fingers bearing pads with circumferential grooves; discs slightly truncate, almost rounded, discs on fingers IV and III largest; (8) fingers fringed with blunt edges; (9) ulnar tubercles absent; (10) heel bearing two small subconical tubercles; inner tarsus tubercles absent; outer edge of tarsus bearing low tubercles in some specimens; (11) inner metatarsal tubercle elliptical, 4-5 times conical outer metatarsal tubercle; plantar supernumerary tubercles on finger I and II; (12) toes weakly fringed, webbing absent; toe V much longer than III; discs approximately equal size and shape as finger discs; (13) dorsum medium to dark brown, W-shaped scapular ridge, outer lines of W black, black dots at base in all; postsacral bar dark brown or black; posterior surface of thighs uniform brown; venter cream; (14) adults small size, males 14.3-16.6 mm, females 19.6-23.5 mm SVL (paratype series).

\section{Description}

Head slightly wider than body, approximately as long as wide; head width of females $36-39 \%$ SVL ( $\overline{\mathrm{x}}=$ $37 \%, N=8$ ), of males $34-39 \%$ SVL ( $\bar{x}=37 \% N=9)$; snout subacuminate (weakly pointed) in dorsal view, in lateral profile rounded; upper jaw slightly overhanging lower jaw at anterior tip; snout of moderate length, eye-nostril distance of females $88-107 \%$ of eye width ( $\overline{\mathrm{x}}=99 \%, N=8)$, of males $68-103 \%(\overline{\mathrm{x}}=87 \%, N=9)$; canthus rostralis from anterior corner of eye to nostril straight in profile, canthus rostralis concave in dorsal view, sharply angled in cross-section; loreal region slightly concave, lips not flared; nostrils slightly protuberant, directed laterally with slight dorsal inclination; interorbital space flat; cranial crests absent, interorbital distance in females $52-62 \%$ of head width $(\overline{\mathrm{x}}=58 \%, N=8)$, in males $52-60 \%(\overline{\mathrm{x}}=56 \%, N=9)$; temporal region vertical, sloping slightly laterally towards jaw; supratympanic ridge absent, postrictal tubercle present, in some specimens line of tubercles posterior to tympanum; tympanum visible, tympanic membrane distinct in most individuals, tympanic annulus barely or slightly discernible, in females tympanum width $34-44 \%$ of eye width ( $\overline{\mathrm{x}}=40 \%, N=9)$, in males tympanum width $30-50 \%$ eye width $(\overline{\mathrm{x}}=37 \%, N=9)$, size and shape 
not sexually dimorphic; distance from tympanum to eye less than diameter of tympanum; choanae mediumsized, round, well within borders of jaws; vomerine odontophores weakly raised, oval, and oblique (less raised in females), slightly smaller than and posterior to choanae, separated medially by approximately two times width of odontophore, females more teeth than males (female median 4 left/5 right, male median 1 left/ 1 right), teeth of males somewhat covered by mucosal tissue; tongue longer than wide, slight posterior notch, attached at front of mouth, posteriorly and laterally not adherent to floor of mouth; in males lateral vocal slits moderate sized, in some male specimens slightly distended subgular vocal sac visible. Nuptial pads absent.

Skin of dorsum smooth to finely shagreened; skin of venter areolate, skin of flanks shagreened; no discoidal fold (that can be discerned from preservation artefact); pair of $\mathrm{W}$-shaped prominent ridges from posterior eyelid to scapular region, two scapular tubercles at posterior end of W; one or two low tubercles on mid-eyelids in some; two low tubercles on dorsum equidistant between posterior end of sacral vertebrae and vent, dark coloured bar in some (postsacral bar); tubercles on elbow absent or low, forearm smooth; palmar tubercle bifid, creased into thirds in some, wider than elongate thenar tubercle; palm bearing elongate tubercles smaller than subarticular tubercles; subarticular tubercles elliptical, supernumerary tubercles on finger I and II, distal subarticular tubercles flattened and rounded; proximal subarticular tubercles subconical; fingers bluntly fringed; all fingers bearing slightly truncate discs on pads, all pads wider than long, pads in decreasing order of size IV=III-II-I (barely wider than digit); decreasing finger length III-IV-II-I.

Heel bearing one or two small subconical tubercles; inner edge of tarsus lack tubercles, outer edge of tarsus low tubercles in some specimens; tarsal fold weak; inner metatarsal tubercle elliptical, 4-5 times longer than smaller and conical outer metatarsal tubercle; subarticular tubercles subconical; toes weakly fringed, lacking webbing; toe IV much longer than V; toe discs wider than long, approximately equal size and shape to finger discs, in order of descending size, IV=V-III-II-I; hindlimbs of moderate length, shank of female 53$60 \% \operatorname{SVL}(\overline{\mathrm{x}}=57 \%, N=8)$, of males $58-63 \% \mathrm{SVL}(\overline{\mathrm{x}}=61 \%, N=9)$.

\section{Colour in preservation}

Central dorsum medium to dark brown, paler on flanks, diagonal brown stripes on flanks, thin white line extending from tip of snout to vent in one specimen; sacral chevron present in some, dark anal triangle present; scapular W-shaped ridge black in most, base of W with two black dots on each side separate or longitudinally joined; background colour of head and scapular region the same colour as dorsum in most specimens, with more grey or darker brown in some specimens, grey interorbital bar in one specimen; prominent dark labial bar at anterior margin of eye; less prominent labial bar at posterior margin of eye in some; eyelids dark grey; dark band at mid-forearm, upper arm lacking markings, elbow with dark spot; brown bands on thigh, shank, and tarsus; inner and posterior surfaces of thighs uniform brown; postsacral dorsal bar dark brown or black; discs of fingers and toes approximately same colour as remainder of digits; venter cream, small melanophores concentrated around jaw and flanks in some specimens; underside of thighs brown, paler line along mid-ventral region of thigh and shank due to absence of melanophores.

One specimen (QCAZ 25273) from Auca 14 Rd, Orellana province (approximately $200 \mathrm{~km} \mathrm{~N}$ of Kapawi Lodge) differs from the paratype series by having a darkened supratympanic ridge. Phylogenetic analysis of mtDNA cytochrome $b$ and $16 \mathrm{~S}$ has confirmed that this specimen is P. achuar (Elmer et al. 2007b, see discussion below).

\section{Colour in life}

Dorsum pale, medium or dark brown, grey brown in some individuals, lighter coloured tinged either grey (e.g. QCAZ 25454) or reddish laterally (e.g. QCAZ 25547); some individuals with scattered cream flecks on dorsum (e.g. QCAZ 25456), some individuals with dark brown or light brown reticulate pattern or stripes on dorsum, some individuals with thin white snout-vent line (e.g. QCAZ 25526); outer lines of W almost invariably black, sometimes accompanied by a reddish line alongside the black (e.g. QCAZ 25454, 25456, 25524, 
25528); yellow-orange patch at base of $\mathrm{W}$ in a few (e.g. QCAZ 25457, 25458, 25463, 25532); often lighter or darker patch from snout to top of head between eyes (e.g. QCAZ 25458, 25461, 25463, 25490, 25492, 25529) or from top of head between eyes to W (e.g. QCAZ 25491) some individuals with tan interorbital bar at top of head (e.g. 25526); venter cream, light speckling on throat and venter in some individuals, throat yellow in some males (e.g. QCAZ 25457, 25458, 25460, 25490, 25523, 25524, 25528, 25529, 25530, 25547). Colour of iris not noted.

\section{Description of holotype}

Measurements (in mm): 21.4 SVL, 12.4 tibia length, 16.1 foot length, 8.3 head width, 7.9 head length, 4.6 IOD, 2.9 END, 2.8 eye width, 1.2 tympanum. Colouration in preservation: light brown dorsum, outer arms of $\mathrm{W}$ thin black, two points at base of $\mathrm{W}$ are separate, tan coloured from the top of the head (between orbitals) to nose, lacking stripes and chevrons, dark bands on forearms, dark bar eye from anterior corner of eye to lip; very little speckling on throat. Colouration in life: "light brown dorsum; black W; orange mark at base of W; lighter from inter-orbital to nose; vague or absent stripes on body, some on legs".

Molecular diversity

Cytochrome $b$ DNA sequences examined for five paratype specimens (QCAZ 25457-25459, 25526, 25527) and the holotype are identical (one haplotype). rDNA 16S sequences for four paratypes (QCAZ $25457,25462,25492,25527$ ) are also identical (one haplotype). GenBank accession numbers (cytochrome b/ 16S): QCAZ 25457 EU130668/ EU130618, QCAZ 25458 EU130669/, QCAZ 25459 EU130670/, QCAZ 25462 /EU130619, QCAZ 25492 /EU130620, QCAZ 25526 EU130671/, QCAZ 25527 EU130672/ EU130621.

\section{Natural History}

Individuals were found in primary forest and presumably can also be found in secondary forest. By night they were often perched on the leaves of low vegetation from 0.2 to $1.3 \mathrm{~m}$ elevation. By day they were found in the leaflitter.

\section{Distribution}

Pristimantis achuar is found in the lowlands of the Pastaza and Napo rivers in southern Ecuador (see Fig. 5). The species is probably more widely distributed into northern Peru.

\section{Pristimantis altamnis sp. nov.}

Figures $2-4$.

Holotype. QCAZ 25311 (field number SC 11271), an adult female collected at Cando community, upper Napo river, parroquía Talag, Napo province, Ecuador (S 01 05.71', W 77 55.47', altitude $680 \mathrm{~m}$ ) on 3 May 2003 by KRE and T. Sugahara.

Paratypes. (12 specimens: 8 males, 2 females, 2 juveniles) QCAZ 25302-304, 25306-310, 25313, 25324-326, and tissue samples were collected in the area of Cando community on 3 May 2003 by KRE and T. Sugahara.

\section{Etymology}

This species is named for the swift headwater rivers of the Amazon River, since it is found at localities near the origins of Ecuador's major rivers (Napo, Pastaza, and Aguarico). The name is a compound adjective of the Latin "altus" for upper and "amnis" for river. 
Diagnosis

(1) Skin on dorsum smooth to finely shagreened with W-shaped occipital-scapular ridges, that on venter areolate; discoidal folds absent; dorsolateral fold absent; (2) tympanum distinct, tympanic annulus present, its width approximately one-third eye width; supratympanic ridge not or barely pigmented; (3) snout subacuminate (weakly pointed) in dorsal view, blunt in lateral profile, canthus rostralis from anterior corner of eye to nostril straight in profile, concave in dorsal view, moderately sharp in cross-section; (4) upper eyelid bearing two low tubercles in some; (5) vomerine odontophores moderately raised, oval, oblique; (6) males with moderately sized vocal slits, nuptial pads absent; (7) first finger shorter than second; all fingers bearing pads with circumferential grooves; discs slightly truncate, those on IV and III largest; (8) fingers bluntly fringed; (9) ulnar tubercles absent; (10) heel bearing small subconical tubercles; inner and outer tarsal tubercles absent; (11) inner metatarsal tubercle raised, oval, 4-5 times longer than conical outer metatarsal tubercle; plantar supernumerary tubercles on finger I and II; (12) toes weakly fringed; webbing absent; toe V much longer than III; discs approximately equal size and shape as finger discs; (13) dorsum dark to medium brown, W-shaped scapular ridge black in most, black dots at base of points of the $\mathrm{W}$ in all, grey interorbital bar in some specimens; postsacral dorsal bar partly or entirely black; posterior surface of thighs uniform brown; venter cream with numerous dark flecks; (14) adults small, males 16.9-19.9 mm $(N=8)$, females 26.9-27.9 mm $(N=3)$ SVL.

\section{Description}

Head slightly wider than body, approximately as long as wide; head width of females $39-41 \%$ SVL ( $\bar{x}=$ $40 \%, N=3)$, of males $37-39 \%$ SVL $(\overline{\mathrm{x}}=38 \%, N=8)$; snout subacuminate (weakly pointed) in dorsal view, in lateral view snout blunt; upper jaw slightly overhanging lower jaw at anterior tip; snout of moderate length, eye-nostril distance of females $104-124 \%$ of eye width $(\overline{\mathrm{x}}=115 \%, N=3)$, of males $89-110 \%(\overline{\mathrm{x}}=100 \%, N=$ 8 ); canthus rostralis from anterior corner of eye to nostril straight in profile, concave in dorsal view, sharply angled in cross-section; loreal region slightly concave, lips not flared; nostrils slightly protuberant, directed laterally with slight dorsal inclination; interorbital space flat; no cranial crests; two low tubercles on mid-eyelids in some specimens; interorbital distance in females $50-53 \%$ of head width $(\overline{\mathrm{x}}=51 \%, N=3)$, in males $47-$ $56 \%(\overline{\mathrm{x}}=51 \%, N=8)$; temporal region vertical, sloping slightly laterally towards jaw; supratympanic ridge not or barely pigmented, not obscuring tympanum, postrictal tubercle present; tympanum visible, tympanic membrane distinct, tympanic annulus present, in females tympanum width $39-40 \%$ of eye width $(\overline{\mathrm{x}}=39 \% \mathrm{~N}$ $=2)$, in males tympanum width $30-37 \%$ of eye width $(\overline{\mathrm{x}}=35 \% N=8)$, size and shape not sexually dimorphic; distance from tympanum to eye less than diameter of tympanum; choanae medium-sized, moderately elliptical, well within borders of jaws; vomerine odontophores moderately raised, oval, and oblique (less raised in females), slightly larger than and posterior to choanae, separated medially by $2-3$ times width of odontophore, females with more teeth than males (females median 4 left $/ 5$ right, males median 2 left $/ 3$ right); tongue longer than wide, posteriorly notched, attached at front of mouth, posteriorly and laterally not adherent to floor of mouth; males with moderate sized lateral vocal slits. Nuptial pads absent.

Skin of dorsum smooth to finely shagreened; skin of venter areolate, skin of flanks shagreened; no apparent discoidal folds (that can be distinguished from preservation artefact); pair of $\mathrm{W}$-shaped prominent ridges from posterior eyelid to scapular region, two posterior tubercles at scapular region end of W; postsacral bar with low tubercles; small (generally low) tubercles on elbow, smooth forearm; palmar tubercle bifid, with crease at base of $U$ in some specimens, larger than elongate thenar tubercle; palm bearing elongate tubercles smaller than subarticular tubercles; subarticular tubercles elliptical, supernumerary tubercles on finger I and II; distal subarticular tubercles flattened and rounded; proximal subarticular tubercles subconical; fingers bluntly fringed; all fingers bearing slightly truncate discs on pads, all pads wider than long, pads in decreasing order of size IV=III-II-I (barely wider than digit); decreasing finger length III-IV-II-I. 
Heel bearing one or two small subconical tubercles; inner and outer edge of tarsus lack tubercles; tarsal fold weak; inner metatarsal tubercle raised, oval, 4-5 times longer than smaller and conical outer metatarsal tubercle; subarticular tubercles subconical, most distal subarticular tubercles flatter and smaller; toes weakly fringed, lacking webbing; toe discs wider than long, approximately equal size and shape to finger discs, in order of descending size, IV-V=III-II-I; hindlimbs of moderate length, shank of female $55-58 \%$ SVL $(\overline{\mathrm{x}}=$ $57 \%, N=3)$, of males $53-63 \%$ SVL $(\overline{\mathrm{x}}=60 \%, N=8)$.

\section{Colour in preservation}

Central dorsum dark to medium brown, paler on flanks, diagonal brown stripes on flanks; sacral chevrons mostly absent, dark anal triangle present; ridge of scapular W-marking black in most, base of W with two black dots on each side separate or longitudinally joined; background colour of head and scapular region brown or grey, similar to that of dorsum; prominent dark labial bar at anterior margin of eye; less prominent labial bar at posterior margin of eye in some; grey interorbital bar in some specimens; upper eyelids grey; dark band at mid-forearm, upper arm lacking markings, elbow with dark spot in some; brown bands on thigh, shank, and tarsus; a few with postsacral dorsal bar black, in most a pair of postsacral dark tubercles; discs of fingers and toes paler than remainder of digits; venter moderately dense distribution of melanophores giving a slightly grey appearance, cream background (under microscope small deposits of guanine pigment visible on ventral aeroli warts), melanophores more concentrated around chin and pectoral region, producing a fine reticulum under chin; underside of thighs brown, lighter line along mid-ventral region of thigh and shank due to absence of melanophores.

Colour in life

Dorsum medium to dark brown, lighter laterally, some individuals with stripes; scapular W mark with black points at base in all, black $\mathrm{W}$ in most, sometimes also outlined in reddish brown; some individuals with light brown patch from snout or top of head, extending to $\mathrm{W}$; venter cream with mottled speckling, throat with yellow flush in some males.

Some specimens from northern Ecuador (610 masl, locality 1 in Fig. 5) (QCAZ 25819-38) had slighter paler dorsal and ventral colouration than most $P$. altamnis. MtDNA sequence data of cytochrome $b$ and 16S confirms their identity to the remainder of the specimens at that locality, and thus part of the $P$. altamnis clade (Elmer et al. 2007b). Colour of iris not noted.

\section{Description of holotype}

Measurements (in mm): 27.6 SVL, 15.2 tibia length, 19.4 foot length, 10.8 head width, 9.8 head length, 5.4 IOD, 4.3 END, 3.5 eye width, 1.3 tympanum width. Colour in preservative: medium brown dorsum, lighter stripes laterally, dark bars on thighs and shanks, thin black line of $\mathrm{W}$, most thick around base tips; venter cream, some light speckling under throat. Colour in life: "medium brown dorsum, grey-brown laterally; black W".

\section{Molecular diversity}

MtDNA cytochrome $b$ sequences examined for eight paratype specimens (QCAZ 25306-25310, 2532425326) are identical (one haplotype). MtDNA 16S sequences for three paratypes (QCAZ 25306, 25309, 25313) are also identical (one haplotype). MtDNA GenBank accession numbers (cytochrome $b / 16 S$ ): QCAZ 25308 EU130652/, QCAZ 25309 EU130653/ EU130607, QCAZ 25310 EU130654/, QCAZ 25313 / EU130608, QCAZ 25324 EU130647/ EU130605, QCAZ 25325 EU130648/, QCAZ 25326 EU130649/.

\section{Natural history}

Individuals were found in primary and secondary forest. By night they are often perched on the leaves of low vegetation. By day they were found in leaflitter. 


\section{Distribution}

Pristimantis altamnis has been found throughout the humid upland tropical forests of eastern Ecuador, at elevations of approximately 400-1000 masl (see Fig. 5). To the east it is replaced by P. kichwarum or $P$. achuar. Its range limits to the north and south are not known. In the upper Napo River area (Jatun Sacha Biological Station), P. altamnis has been found sympatrically with P. kichwarum.

\section{Pristimantis kichwarum sp. nov.}

Figures 2-4, 6 .

Holotype. QCAZ 18128 (field number SC7783), an adult male collected at Jatun Sacha Biological Station, parroquía Ahuano, Napo province, Ecuador (S 01 ${ }^{\circ} 04.45^{\prime}$, W 77³6.93', altitude $472 \mathrm{~m}$ ), on 14 November 2001 by KRE and F. Ayala-Varela. MtDNA cytochrome $b$ Genbank accession number EF581033.

Paratypes. (45 specimens: 29 males, 13 females, 3 juveniles) QCAZ 18023, 18027, 18030, 18033, 18039, 18041, 18045, 18053, 18069, 18071, 18077, 18085, 18089, 18092, 18096, 18098, 18110, 18112, 18117, 18126, 18132, 18137, 18139, 18153, 18165, 25287, 25288, 25290, 25291, 25295, 25552, 25554, $25555,25558,25561,25564,25573,25575,25579,25580,25751,25757,25759,25773$, and 25782 were collected between 4 November 2001 and 14 April 2003 from Jatun Sacha Biological Station and adjacent areas (Librarius Study Center and Inner Vision Lodge [currently known as Arajuno Jungle Lodge]) (Appendix 1).

Referred. Specimens collected adjacent to Jatun Sacha Biological Station (at Inner Vision Lodge) by KRE and T. Sugahara, QCAZ 25752 (male) 13 April 2003 and QCAZ 25783 (male) 17 April 2003.

\section{Etymology}

This species is named for the indigenous Kichwa communities in the Oriente of Ecuador. They are recognized in this small collective way as a token of appreciation for the engagement of individuals and communities in this research, and for sharing their biodiversity and knowledge. The patronym is a Latin feminine plural genitive of the nation name.

\section{Diagnosis}

(1) Skin of dorsum smooth to finely shagreened with W-shaped occipital-scapular ridges, that of venter areolate; no obvious discoidal folds; dorsolateral fold absent; (2) tympanum and tympanic membrane distinct, tympanic annulus barely or slightly discernible, tympanum width approximately one-third eye width; supratympanic ridge dark; (3) snout subacuminate (weakly pointed) in dorsal view, rounded in lateral profile, canthus rostralis from anterior corner of eye to nostril slightly convex in lateral profile, concave in dorsal view, sharply angled in cross-section; (4) upper eyelid with or without two low tubercles; cranial crests absent; (5) odontophores moderately raised, oval, oblique; (6) males with moderately sized vocal slits, nuptial pads absent; (7) first finger shorter than second; all fingers bearing pads with circumferential grooves; discs slightly truncate, almost rounded, those on IV and III largest; (8) fingers slightly fringed; (9) ulnar tubercles very low or absent; (10) heel bearing small subconical tubercles; tarsal tubercles absent, tarsal fold weak; (11) inner metatarsal tubercle raised, elliptical, lateral margin more convex than medial margin, 4-5 times longer than conical outer metatarsal tubercle; few supernumerary plantar tubercles; (12) toes weakly fringed, lacking webbing; toe V much longer than III; discs approximately of equal size and shape as finger discs; (13) dorsum dark to light brown; W-shaped scapular ridge black in some, black dots at the lower points of the W in all; canthal stripe black; postsacral bar slightly or completely black; posterior surface of thighs brown; venter cream with some dark flecks; (14) adults small, males 17.5-21.9 mm $(N=30)$, females 24.4-27.0 mm $(N=$ 13) SVL. 


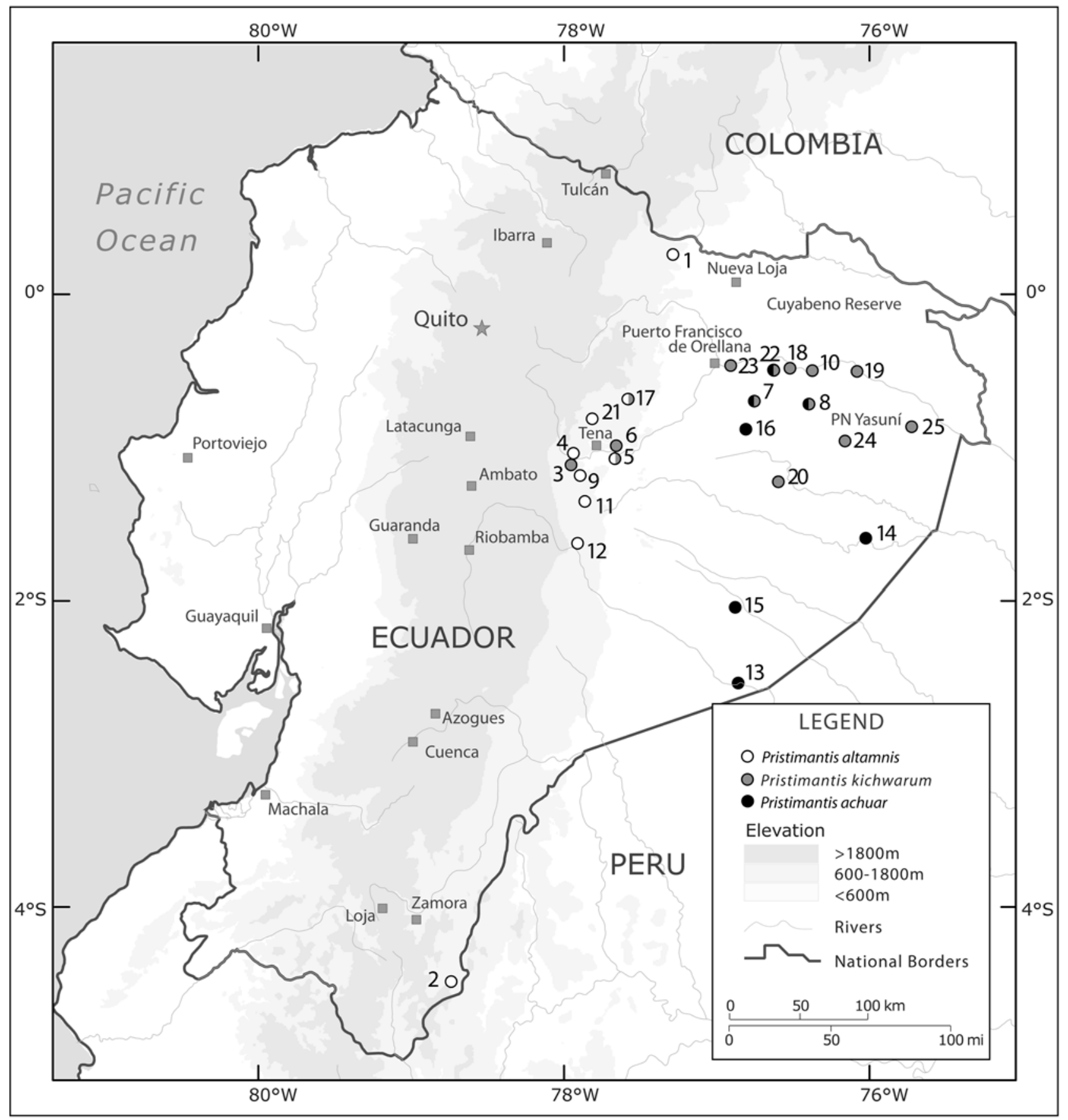

FIGURE 5. Map of localities for reviewed specimens of $P$. altamnis (white dot), P. kichwarum (grey dot), and $P$. achuar (black dot). The general area of the Cuyabeno Reserve and Yasuní National Park are noted, as mentioned in the text for some collections. For simplicity, some nearby localities share a dot. (1) Chonta Yacu, Lumbaqui; (2) Centro Shuar Yawi; (3) Serena; (4) Talag or Cando; (5) Jatun Sacha Biological Station and Arajuno Jungle Lodge; (6) Puca Chicta, Misahua1lí; (7) Auca 14 Rd near Dayuma; (8) Parque Nacional Yasuní: Estación Científica, Onkonegare, and pozo Capiron; (9) Llanganates Mountains, Canton Arosamena Tola; (10) La Selva Lodge, Pañacocha; (11) Y of road Tena to Puyo, Canton Sta Clara; (12) Fundación Hola Vida, El Porvenir; (13) Kapawi Lodge; (14) Lorocachi; (15) Petrolera Garza 1, Montalvo; (16) Bloque Shiripuno, Parque Nacional Yasuní; (17) Rio Huataracu, via Hollín-Loreto; (18) Indillama; (19) Yuturi; (20) Bataburo Lodge, Rio Tiguño; (21) Santa Rita; (22) Parque Nacional Yasuní, Carretera Pompeya Sur-Iro Km 21, 38 or 41; (23) Comuna El Descanso; (24) Parque Nacional Yasuní Road to MAXUS km 107 and AMO 1; (25) Parque Nacional Yasuní Bloque 31. 


\section{Description}

Head slightly wider than body, approximately as long as wide; head width of females 36-39\% SVL ( $\overline{\mathrm{x}}=$ $37 \%, N=5)$, of males $33-39 \% \mathrm{SVL}(\overline{\mathrm{x}}=36 \%, N=9)$; snout subacuminate (weakly pointed) in dorsal view, in lateral view rounded; upper jaw overhanging lower jaw at anterior tip; snout of moderate length, eye-nostril distance of females $90-98 \%$ of eye width $(\overline{\mathrm{x}}=94 \%, N=5)$, of males $78-104 \%(\overline{\mathrm{x}}=93 \%, N=9)$; canthus rostralis from anterior corner of eye to nostril slightly convex in lateral profile, canthus rostralis concave in dorsal view, sharply angled in cross-section; loreal region slightly concave, lips not flared; nostrils slightly protuberant, directed laterally with slight dorsal inclination; interorbital space flat; cranial crests absent, interorbital distance in females $49-58 \%$ of head width $(\overline{\mathrm{x}}=53 \%, N=5)$, in males $52-61 \%(\overline{\mathrm{x}}=57 \%, N=9)$; two low tubercles on mid eyelids in some specimens; temporal region vertical, sloping slightly laterally towards jaw; supratympanic ridge, darkened, not obscuring tympanum, postrictal tubercle present; tympanum visible, tympanic membrane distinct, tympanic annulus barely or slightly discernable, in females tympanum width 27$44 \%$ of eye width ( $\overline{\mathrm{x}}=34 \%, N=5)$, in males tympanum width $29-43 \%$ of eye width $(\overline{\mathrm{x}}=33 \%, N=9)$, size and shape not sexually dimorphic; distance from eye to tympanum less than diameter of tympanum; choanae medium-sized, round, moderately elliptical, well within borders of jaws; odontophores moderately raised and oblique (less raised in females), slightly larger than and posterior to choanae, separated medially by 2-3 times width of odontophore, females with more teeth than males (median 5 left $/ 5$ right in females, median 2 left/2 right in males), teeth of males somewhat covered by mucosal tissue in some specimens; tongue longer than wide, with slight posterior notch, attached at front of mouth, posteriorly and laterally not adherent to floor of mouth; vocal slits lateral, moderate sized; in some male specimens slightly distended subgular vocal sac visible. Nuptial pads absent.

Skin of dorsum smooth to finely shagreened; skin of venter areolate, skin of flanks shagreened; no apparent discoidal folds (that can be distinguished from preservation artefact); pair of $\mathrm{W}$-shaped prominent ridges from posterior eyelid to scapular region, two posterior scapular tubercles located at base of W; postsacral bar with low tubercles; small (generally low) tubercles on elbow, smooth forearm, ulnar tubercles low or absent; palmar tubercle bifid, crease at base of $U$ in most specimens, larger than elongate thenar tubercle; elongate palmar tubercles smaller than subarticular tubercles; subarticular tubercles elliptical, raised and flat in lateral view, supernumerary tubercles on finger I and II; distal subarticular tubercles flattened and rounded; proximal subarticular tubercles subconical; fingers with weak lateral fringes; all fingers bearing discs on pads, all pads wider than long, slightly truncate, equally distinct on fingers IV-II, pads in decreasing order of size IV=III-II-I (barely wider than digit); decreasing finger length III-IV-II-I.

Heel bearing one or two small subconical tubercles; inner and outer edge of tarsus lacking tubercles; tarsal fold weak; inner metatarsal tubercle raised, elliptical and lateral margin more convex than medial margin, 4-5 times longer than smaller conical outer metatarsal tubercle; subarticular tubercles subconical, most distal subarticular tubercles flatter and smaller; toes weakly fringed, lacking webbing; toe discs wider than long, slightly truncate, approximately equal size to finger discs, in order of descending size, IV-V=III-II-I; hindlimbs of moderate length, shank of female $53-58 \%$ SVL $(\overline{\mathrm{x}}=55 \%, N=5)$, of males $54-60 \%$ SVL ( $\overline{\mathrm{x}}=58 \%$, $N=9$ ).

\section{Colour in preservation}

Central dorsum dark to light brown, paler on flanks, diagonal brown stripes on flanks, thin white mid-dorsal line extending from tip of snout to vent in some (e.g. QCAZ 18030, 18110, 18126, 25554, 25558); sacral chevron present in some, dark anal triangle present; scapular W-shaped ridge, outer lines of W black, inner lines of $\mathrm{W}$ black in some, and/or with white along ridge (in individuals with thin white snout-to-vent line), base of $\mathrm{W}$ with two black dots on each side separate or longitudinally joined; background colour of head and scapular region brown or grey, approximately same colour as dorsum; canthal stripe black; prominent dark labial bar at anterior margin of eye; less prominent labial bar at posterior margin of eye in some; supratym- 
panic ridge with thin black line; eyelids grey; dark band at mid-forearm, upper arm lacking markings, elbow with dark spot in some; brown bars on thigh, shank, and tarsus; anterior and posterior surfaces of thighs uniform brown; postsacral dorsal bar partially or fully black; discs of fingers and toes paler than remainder of digits; venter cream (under microscope small deposits of guanine pigment visible on ventral areolar warts) with small dark spotting, more concentrated around jaw and flank; ventral surface of thighs brown, mid-ventral region of thigh and shank with absence of melanophores producing a lighter line.

\section{Colour in life}

Dorsum light to medium brown, lighter laterally, occasionally with posterio-lateral stripes and/or reticulate pattern, with or without darker mid-dorsal chevron(s); some specimens with reddish tinge lateral to $\mathrm{W}$ and around upper arms (e.g. QCAZ 18085, 18165), some specimens with random grey dorsal flecks (e.g. QCAZ $18033,18039,18069,18077,18085,18132,18137,18165)$, some specimens with thin white snout-vent line (e.g. QCAZ 18030, 18110, 18126, 25554, 25558); points at base of scapular W black, W-shaped ridge most commonly black (except, e.g. QCAZ 18071, 18092); some specimens with lighter brown patch extending from nose to top of head (between eyes) (e.g. QCAZ 18030, 18077, 18085, 18139) or to W (e.g. QCAZ 18117), or extending from top of head (between eyes) to W (e.g. QCAZ 18069); venter cream, lightly specked especially around throat, throat tinged with yellow in some males (e.g. QCAZ 25552, 25555, 25558, 25564). Iris is bronze with a darker lateral stripe, lighter bronze above and darker below median.

\section{Description of the holotype}

Measurements (in mm): SVL 20.2, tibia length 12.3, foot length 15.7, head width 7.6, head length 7.9, IOD 3.9, END 2.9, eye width 2.6, tympanum width 0.9. Colour in preservative: medium brown with reticulate patterning, scapular W marking white with very thin black outline, base points of W black, thin white snoutvent line, finger and toe pads lighter than digits. Right foot of the holotype with unusually small toe discs. Colour in life: "mottled medium dark brown dorsum, black and light (paler) outlines of scapular W, thin white snout-vent line".

\section{Molecular diversity}

MtDNA cytochrome $b$ sequences examined for 44 paratype specimens and the holotype resulted in five haplotypes with a maximum uncorrected $p$-distance between them of $0.63 \%$. MtDNA 16S sequences for six paratypes resulted in three haplotypes with a maximum uncorrected $p$-distance of $0.39 \%$. See Appendix 1 for cytochrome $b$ and/or $16 \mathrm{~S}$ GenBank accession numbers.

\section{Natural history}

Individuals were found in primary and secondary forest. By night they were found perched on the leaves or stems of low vegetation from 0.2 to $1.5 \mathrm{~m}$ elevation. By day they were found in the leaflitter. The following specimens were collected in amplexus: QCAZ 25287 (paratype female) with 25288 (paratype male), 25751 (paratype female) with 25752 (referred male), and 25782 (paratype female) with 25783 (referred male).

\section{Distribution}

Pristimantis kichwarum has been found throughout the humid tropical forests of eastern lowlands of Ecuador in the Napo, Orellana, and Sucumbíos provinces, at elevations of approximately 500 masl and below (see Fig. 5). The extent of its distribution to the east and north is not known. The species is apparently replaced by P. achuar to the south in the Pastaza basin. In the upper regions of the Napo River (Jatun Sacha Biological Station), P. kichwarum has been found sympatrically with P. altamnis. 
TABLE 1. Morphological characters used to distinguish various upper Amazonian or east Andean Eleutherodactylus ( + indicates presence, - indicates absence, ? indicates not available or inconclusive).

\begin{tabular}{|c|c|c|c|c|c|c|}
\hline & $\begin{array}{l}\mathrm{W} \text { on scapular } \\
\text { region }\end{array}$ & SVL (mm) & $\begin{array}{l}\text { Canthal } \\
\text { stripe }\end{array}$ & $\begin{array}{l}\text { Eyelid } \\
\text { tubercles }\end{array}$ & Tympanum & $\begin{array}{l}\text { Thigh colour, } \\
\text { posterior surface }\end{array}$ \\
\hline P. achuar & $\begin{array}{l}\text { present as thin } \\
\text { ridge, usually } \\
\text { black }\end{array}$ & $\begin{array}{l}\text { 우 19.6-23.5; } \\
\text { 어 14.3-16.6 }\end{array}$ & - & + & visible & uniform brown \\
\hline P. altamnis & $\begin{array}{l}\text { present as thin } \\
\text { ridge, usually } \\
\text { black }\end{array}$ & $\begin{array}{l}\text { 우 18.8-28.3; } \\
\text { 어 15.1-22.3 }\end{array}$ & - & + & visible & uniform brown \\
\hline P. kichwarum & $\begin{array}{l}\text { present as thin } \\
\text { ridge, usually } \\
\text { black }\end{array}$ & $\begin{array}{l}\text { ㅇ 19.3-30.2; } \\
\text { ox 15.2-22.4 }\end{array}$ & + & + & visible & uniform brown \\
\hline P. acuminatus & absent & $\begin{array}{l}\text { ㅇ } 26-34 ; \\
\text { or 17-23[9] }\end{array}$ & $+[3]$ & - & concealed[3] & pale green \\
\hline P. carvalhoi & $\begin{array}{l}\text { as a marking, } \\
\text { present or } \\
\text { absent[9] }\end{array}$ & $\begin{array}{l}\text { ㅇ 17.4-21.9; } \\
\text { ox 12.8-18.2[2] }\end{array}$ & $-[9]$ & $+[9$ photo $]$ & $\begin{array}{c}\text { concealed[1] or } \\
\text { barely evident } \\
\text { [9] }\end{array}$ & $?$ \\
\hline P. croceoinguinis & $\begin{array}{l}\text { present as low } \\
\text { thick ridge }\end{array}$ & $\begin{array}{c}\text { क } 24.9 ; \\
\text { o }^{x} 17.2-21.6[8]\end{array}$ & - & + & concealed[6] & grey \\
\hline P. frater & $?$ & $\begin{array}{l}\text { ㅇ 23.7-25.9; } \\
\text { ơ 15.6-18.8; [1] }\end{array}$ & $?$ & $?$ & visible[8] & uniform brown[8] \\
\hline P. incomptus & $\begin{array}{l}\text { present as mark- } \\
\text { ing [1] }\end{array}$ & $\begin{array}{c}\text { 우 27.5-45.4; } \\
\text { ơ 21.7-27.9[1] }\end{array}$ & $-[8]$ & $-[1]$ & visible[1] & brown[1] \\
\hline P. lanthanites & $\begin{array}{l}\text { absent, but with } \\
\text { chevron mark- } \\
\text { ings and scapular } \\
\text { points }\end{array}$ & $\begin{array}{l}\text { 우 18-23; } \\
\text { ơ 13-17[4] }\end{array}$ & usually[3] & + & visible & $\begin{array}{l}\text { brown with small } \\
\text { yellow-tan flecks[3] }\end{array}$ \\
\hline P. librarius & $\begin{array}{l}\text { no, but some pale } \\
\text { chevron markings }\end{array}$ & $\begin{array}{l}\text { ㅇ 16-19; } \\
\text { ơ 13-17[4] }\end{array}$ & - & $\begin{array}{l}\text { two low } \\
\text { tubercles }\end{array}$ & $\begin{array}{l}\text { partially con- } \\
\text { cealed }[8]\end{array}$ & reddish in life \\
\hline P. martiae & $\begin{array}{l}\text { no, but other } \\
\text { markings } \\
\text { present[4] }\end{array}$ & $\sigma^{x} 15.3-18.7[7]$ & $-[4]$ & $\begin{array}{l}\text { low flat } \\
\text { warts[4] }\end{array}$ & concealed $[1]$ & brown \\
\hline P. paululus & $\begin{array}{l}\text { some scapular } \\
\text { markings, but not } \\
\text { a ridge }\end{array}$ & $\begin{array}{l}\text { ㅇ } 23 \text {; } \\
\text { ơ } 19[3]\end{array}$ & $+[3]$ & - & visible[3] & greyish-tan[3] \\
\hline P. pecki & $\begin{array}{l}\text { absent; brown } \\
\text { interorbital trian- } \\
\text { gle[7] }\end{array}$ & $\begin{array}{l}\text { 우 24.6-31.3; } \\
\text { ơ 19.6-22.5[8] }\end{array}$ & $-[7]$ & $\begin{array}{l}+ \text { nonpun- } \\
\text { gent[7] }\end{array}$ & prominent [7] & uniform brown[7] \\
\hline P. pseudoacuminatus & absent & $\begin{array}{l}\text { 우 21.9-26.8; } \\
\text { ơ 15.7-22.0[6] }\end{array}$ & $\begin{array}{l}-,+ \text { in } \\
\text { some[3] }\end{array}$ & $-[3]$ & visible[3] & $\begin{array}{l}\text { uniform pale green } \\
\text { to grey-green[3] }\end{array}$ \\
\hline P. quaquaversus & absent & $\begin{array}{c}\text { 우 24.6-31.3; } \\
\text { ơ 19.6-22.5[4] }\end{array}$ & - & + & concealed[3] & $\begin{array}{l}\text { purplish with white } \\
\text { flecks[3] }\end{array}$ \\
\hline P. variabilis & absent & $\begin{array}{l}\text { 우 } 22.0-27.0 \text {; } \\
\quad{ }^{\pi} 19[3]\end{array}$ & $+[6]$ & $?$ & visible & brown[6] \\
\hline
\end{tabular}


TABLE 1 (continued).

\begin{tabular}{|c|c|c|c|c|c|c|}
\hline & $\begin{array}{l}\text { Dorsum colour } \\
\text { in life }\end{array}$ & Venter colour & Dorsal skin & $\begin{array}{l}\text { Canthus shape, } \\
\text { cross-section }\end{array}$ & $\begin{array}{l}\text { Snout, dor- } \\
\text { sal view }\end{array}$ & $\begin{array}{l}\text { Elevation } \\
\text { (masl) }\end{array}$ \\
\hline P. achuar & medium brown & cream & $\begin{array}{l}\text { smooth to } \\
\text { finely } \\
\text { shagreened }\end{array}$ & sharp & subacuminate & $255-240$ \\
\hline P. altamnis & $\begin{array}{l}\text { medium to dark } \\
\text { brown }\end{array}$ & $\begin{array}{c}\text { cream with brown } \\
\text { flecks forming retic- } \\
\text { ulate }\end{array}$ & $\begin{array}{l}\text { smooth to } \\
\text { finely } \\
\text { shagreened }\end{array}$ & sharp & subacuminate & $400-1000$ \\
\hline P. kichwarum & $\begin{array}{l}\text { light to dark } \\
\text { brown }\end{array}$ & $\begin{array}{l}\text { cream, some brown } \\
\text { flecks }\end{array}$ & $\begin{array}{l}\text { smooth to } \\
\text { finely } \\
\text { shagreened }\end{array}$ & sharp & subacuminate & $240-515$ \\
\hline P. acuminatus & green & white & smooth & sharp & $\begin{array}{c}\text { pointed } \\
\text { (acuminate) }\end{array}$ & $300-1000[2]$ \\
\hline P. carvalhoi & dull brown[9] & $\begin{array}{l}\text { cream with small } \\
\text { brown flecks; groin } \\
\text { yellow[9] }\end{array}$ & $\begin{array}{l}\text { finely tuber- } \\
\text { culate[9] }\end{array}$ & $\begin{array}{l}\text { rounded[9 } \\
\text { photo] }\end{array}$ & $\begin{array}{l}\text { moderately } \\
\text { long and } \\
\text { pointed[9] }\end{array}$ & lowland[5] \\
\hline P. croceoinguinis & $\begin{array}{l}\text { yellow-brown } \\
\text { to brown[6], } \\
\text { grey }\end{array}$ & $\begin{array}{l}\text { grey to black (usu- } \\
\text { ally brown) flecked } \\
\text { with cream[6]; } \\
\text { orange mark in groin }\end{array}$ & pustular & $\begin{array}{l}\text { moderately } \\
\text { sharp }\end{array}$ & subacuminate & $\begin{array}{l}\text { 200-400m[5]; } \\
\text { also higher } \\
\text { altitude[KRE] }\end{array}$ \\
\hline P. frater & $?$ & $?$ & $?$ & rounded[8] & $\begin{array}{l}\text { subacumi- } \\
\text { nate }[8]\end{array}$ & $1000-1600[5]$ \\
\hline P. incomptus & $\begin{array}{l}\tan \text { with darker } \\
\text { brown mark- } \\
\text { ings[1] }\end{array}$ & $\begin{array}{l}\text { brown, grey, dirty } \\
\text { cream with brown } \\
\text { flecks[1] }\end{array}$ & $\begin{array}{l}\text { bearing low } \\
\text { flat warts[1] }\end{array}$ & rounded[1] & $\begin{array}{l}\text { subacuminate } \\
\text { to round[1] }\end{array}$ & $1370-1910[5]$ \\
\hline P. lanthanites & olive-brown & $\begin{array}{l}\text { cream-white with } \\
\text { grey flecks[3]; } \\
\text { brown with yellow } \\
\text { mottling; throat grey/ } \\
\text { brown with strong } \\
\text { medial yellow/white } \\
\text { stripe }\end{array}$ & $\begin{array}{l}\text { dorso-lateral } \\
\text { dermal folds }\end{array}$ & $\begin{array}{l}\text { moderately } \\
\text { sharp }\end{array}$ & $\begin{array}{l}\text { long and sub- } \\
\text { acuminate }\end{array}$ & $200-1630[5]$ \\
\hline P. librarius & golden tan & stippled with brown & smooth & $\begin{array}{l}\text { moderately } \\
\text { sharp }\end{array}$ & $\begin{array}{c}\text { almost } \\
\text { pointed } \\
\text { (acuminate) }\end{array}$ & $220-560[5]$ \\
\hline P. martiae & brown & $\begin{array}{l}\text { pale brown with } \\
\text { brown suffusion[4] }\end{array}$ & $\begin{array}{c}\text { finely } \\
\text { shagreened } \\
\text { with low } \\
\text { warts[4] }\end{array}$ & $\begin{array}{l}\text { moderately } \\
\text { sharp }\end{array}$ & $\begin{array}{l}\text { subacuminate } \\
\text { to rounded } \\
\text { with pointed } \\
\text { tip[4] }\end{array}$ & $100-1300[5]$ \\
\hline P. paululus & dull green[3] & $\begin{array}{l}\text { green with white } \\
\text { spots[4] }\end{array}$ & smooth[4] & slightly rounded & rounded[3] & $300-600[5]$ \\
\hline P. pecki & $\begin{array}{l}\text { brown, darker } \\
\text { laterally[7] }\end{array}$ & cream[7] & smooth[7] & round[7] & $\begin{array}{l}\text { subacumi- } \\
\text { nate[7] }\end{array}$ & $1550-1830[7]$ \\
\hline P. pseudoacuminatus & green[3] & white[3] & smooth[3] & $\begin{array}{l}\text { gently } \\
\text { rounded[3] }\end{array}$ & $\begin{array}{l}\text { narrow and } \\
\text { rounded[3] }\end{array}$ & $330-570[2]$ \\
\hline P. quaquaversus & $\begin{array}{l}\text { tan, reddish } \\
\text { brown }\end{array}$ & bronze-white[3] & smooth & slightly rounded & subacuminate & 200-1900[5] \\
\hline P. variabilis & $\begin{array}{l}\text { grey, brown, or } \\
\text { dark brown[6] }\end{array}$ & $\begin{array}{l}\text { cream to white with } \\
\text { black flecks, black- } \\
\text { edged yellow-white } \\
\text { area in groin[6] }\end{array}$ & shagreened[6] & well-defined[6] & acuminate[6] & $100-600[5]$ \\
\hline
\end{tabular}

[1] Lynch and Duellman 1980; [2] Lynch 1980; [3] Duellman 1978; [4] Lynch 1974; [5] IUCN et al.; [6] Lynch 1968; [7] Duellman \& Lynch 1988; [8] Flores \& Vigle 1994; [9] Rodriguez \& Duellman 1994; [no citation] KRE/DCC review of QCAZ specimens. 


\section{Discussion}

Distinguishing Species:

Morphology

The three new species could be most easily confused with the sympatric congeners Pristimantis martiae, P. croceoinguinis, P. librarius, or $P$. variabilis (see Table 1 for notes on the characters of these and other upper Amazonian species). Pristimantis achuar, P. altamnis, and P. kichwarum can be distinguished from these other species most reliably by the presence of a thin $\mathrm{W}$-shaped epidermal ridge (not just black markings) along the scapular region, usually fully or mostly black: no other species in the area has this ridge. Pristimantis martiae has a shorter snout than P. achuar, P. altamnis, or P. kichwarum and a pale brown venter. Pristimantis croceoinguinis has a softer canthus, eyes placed more closely together (i.e., smaller IOD), a taller head in profile, grey dorsal and ventral colouration, and a distinctive orange spot in the groin. Pristimantis librarius prefers secondary forest and disturbed habitats such as grazing areas and new successional growth, has a light brown ventral colouration, and an orangish or reddish colouration on the anterior, posterior, and ventral surfaces of the thighs in life. The three new species described here are easily distinguished from $P$. variabilis by its long snout, large pale brown melanophores on the venter, a more rounded canthus, more robust digits, and the presence of a yellowish (in life, white in preservation) patch in the groin.

A more difficult task is to distinguish $P$. achuar, $P$. altamnis, and $P$. kichwarum from each other. Other authors have stated that $P$. ockendeni lacks a canthal stripe (e.g., Duellman 1978; Lynch 1980; Flores \& Vigle 1994; Duellman \& Pramuk 1999). In reviewing Peruvian and Ecuadorean E. ockendeni, Lynch (1974) does not mention either presence or absence of a canthal stripe. We have found the canthal stripe to be an important distinguishing character that corresponds to the mitochondrial lineages (Figure 7). Pristimantis kichwarum, which has been found so far only at elevations below $510 \mathrm{~m}$, has a black canthal stripe, a dark supratympanic ridge, and a cream venter with melanophores producing a pattern of brown flecking. Pristimantis altamnis is generally found in the uplands (400 to 1000 masl) but is also sympatric with P. kichwarum at a few localities (e.g., Jatun Sacha Biological Station). Pristimantis altamnis can be distinguished from P. kichwarum by lacking a black canthal stripe and having a darker ventral colouration (due to a heavier pattern of flecks). In the specimens we reviewed, no P. altamnis specimen had a thin white snout-vent line as was found occasionally in $P$. kichwarum and $P$. achuar. An additional subtle but consistent difference between the new species is the shape of the head in profile: in P. kichwarum the area of the snout from eye to nostril is slightly convex in profile and the snout somewhat rounded, while in P. altamnis and P. achuar the profile from nose to eye is straight and the snout blunter. Pristimantis kichwarum and P. altamnis are the same body size (Table 2). Pristimantis achuar lacks a canthal stripe and supratympanic ridge and can be distinguished from $P$. altamnis by a much paler venter (near absence of melanophores) and a smaller body size (Table 2). Additionally, P. achuar has a lowland geographic distribution (to date less than 350 masl). Figures $2-4$ and Table 1 illustrate the morphological differences between the three new species.

In addition to the specimens ascribed to new species (see Specimens examined), we reviewed specimens from Reserva de Producción Faunística Cuyabeno in the north of Ecuador. We identified two morphs in that reserve: one lacks a canthal stripe and has a darker venter (like P. altamnis) (QCAZ 27826, 27831, 27833, 27938, 27985, 28019, 28021, 28026, 28030, 28032, 28048, 28049, 28058, 28140, 28183, 28195); the other morph has a black canthal stripe and a paler venter (like P. kichwarum) (QCAZ 28041, 27873, 28087, 25576, 25577). MtDNA sequences have shown QCAZ 25576 and 25577 to be sister taxa to $P$. kichwarum (approximately $6 \%$-distance at cytochrome $b$ ) and resolve into the same clade as P. kichwarum relative to P. altamnis and $P$. achuar (Figure 7 and Elmer et al. 2007b). The specimens of these two morphs were collected from three different localities in the reserve, separated by $10-80 \mathrm{~km}$. In general, the specimens lacking a canthal stripe (like $P$. altamnis) are from the western portion of the reserve while those from the more eastern portion have a canthal stripe (like P. kichwarum). We have declined to assign either of these morphs to any of the three 
new species because sample sizes are too small and there are many juveniles in the sample. However, it is most probable, based on morphology and genetics, that the specimens with a black canthal stripe are $P$. kichwarum.

TABLE 2. Mean and standard deviation (in mm) of P. achuar, P. altamnis, and P. kichwarum morphological measurements by sex.

\begin{tabular}{|c|c|c|c|c|c|c|c|c|c|}
\hline \multirow[t]{2}{*}{ Females } & \multicolumn{3}{|c|}{ P. achuar } & \multicolumn{3}{|c|}{ P. altamnis } & \multicolumn{3}{|c|}{ P. kichwarum } \\
\hline & Mean & Std Dev & $\mathrm{N}$ & Mean & Std Dev & $\mathrm{N}$ & Mean & Std Dev & $\mathrm{N}$ \\
\hline SVL & 21.8 & 1.3 & 8 & 25.5 & 3.1 & 15 & 25.3 & 2.9 & 32 \\
\hline Femur Length & 11.0 & 0.7 & 8 & 12.6 & 1.5 & 15 & 12.2 & 1.3 & 28 \\
\hline Forelimb Length & 10.3 & 0.2 & 8 & 12.4 & 1.5 & 15 & 11.7 & 1.3 & 26 \\
\hline Head Width & 8.0 & 0.4 & 8 & 9.7 & 1.3 & 15 & 9.3 & 1.1 & 28 \\
\hline Foot Length & 16.1 & 0.7 & 8 & 18.9 & 2.1 & 15 & 18.1 & 1.9 & 24 \\
\hline Internarial Distance & 1.9 & 0.1 & 8 & 2.3 & 0.2 & 15 & 2.2 & 0.3 & 28 \\
\hline Tibia Length & 12.4 & 0.4 & 8 & 14.5 & 1.6 & 15 & 14.1 & 1.3 & 28 \\
\hline IOD & 4.5 & 0.1 & 8 & 5.2 & 0.7 & 15 & 4.9 & 0.5 & 28 \\
\hline Eye to Nostril & 2.8 & 0.2 & 8 & 3.5 & 0.6 & 15 & 3.4 & 0.4 & 28 \\
\hline \multirow[t]{2}{*}{ Males } & \multicolumn{3}{|c|}{ P. achuar } & \multicolumn{3}{|c|}{ P. altamnis } & \multicolumn{3}{|c|}{ P. kichwarum } \\
\hline & Mean & Std Dev & $\mathrm{N}$ & Mean & Std Dev & $\mathrm{N}$ & Mean & Std Dev & $\mathrm{N}$ \\
\hline SVL & 15.5 & 0.8 & 10 & 18.5 & 1.5 & 59 & 18.8 & 1.6 & 74 \\
\hline Femur Length & 8.8 & 0.2 & 2 & 9.6 & 0.8 & 48 & 9.6 & 0.7 & 53 \\
\hline Forelimb Length & 7.9 & 0.4 & 2 & 9.1 & 0.9 & 47 & 9.3 & 0.6 & 50 \\
\hline Head Width & 5.9 & 0.3 & 2 & 7.0 & 0.6 & 48 & 7.1 & 0.5 & 53 \\
\hline Foot Length & 12.4 & & 1 & 14.3 & 1.3 & 45 & 14.4 & 1.0 & 37 \\
\hline Internarial Distance & 1.5 & 0.0 & 2 & 1.7 & 0.2 & 48 & 1.8 & 0.2 & 53 \\
\hline Tibia Length & 9.6 & 0.2 & 2 & 11.1 & 0.9 & 48 & 11.3 & 0.6 & 53 \\
\hline IOD & 3.3 & 0.4 & 2 & 3.7 & 0.5 & 48 & 3.9 & 0.4 & 53 \\
\hline Eye to Nostril & 2.0 & 0.2 & 2 & 2.4 & 2.4 & 47 & 2.5 & 0.3 & 52 \\
\hline
\end{tabular}

Molecular differentiation

The observed mtDNA sequence divergence between P. achuar, P. altamnis, and P. kichwarum is high. Cytochrome $b$ uncorrected $p$-distance between the new species' paratypes is $17.1 \%$ between $P$. achuar and $P$. altamnis, $14.9-16.1 \%$ between $P$. kichwarum and $P$. achuar, and $11.8-12.7 \%$ between $P$. kichwarum and $P$. altamnis. 16S difference is approximately half that of cytochrome $b$ : between $P$. achuar and $P$. altamnis is 8.9\%; between P. achuar and P. kichwarum 8.5-8.9\%; between P. altamnis and P. kichwarum 5.3-5.6\%. 
With larger geographic sampling than the present study, DNA sequence data compiled from Elmer et al. (2007b) show that maximum intraspecific uncorrected $p$-distance for cytochrome $b$ is low: $4.6 \%$ within $P$. achuar (their "Southeastern Clade"), 4.9\% within P. altamnis ("Upland Clade"), and 6.4\% within P. kichwarum ("Lowland Clade"). However, cytochrome $b$-distances between clades are high: 16.4-17.8\% between P. achuar and P. altamnis, 14.9-16.1\% between P. achuar and P. kichwarum, and 12.0-13.3\% between P. altamnis and P. kichwarum. At $16 \mathrm{~S}$, maximum distance within species is $1.9 \%$ within $P$. achuar, $1.7 \%$ within $P$. altamnis, and $3.4 \%$ within P. kichwarum. $P$-distances between species range from $8.7-9.4 \%$ between $P$. achuar and $P$. altamnis, 8.5-9.2\% between $P$. achuar and $P$. kichwarum, and $4.5-5.8 \%$ between $P$. altamnis and P. kichwarum.

The sister taxon relationship of $P$. altamnis to $P$. kichwarum relative to $P$. achuar is also reflected in a phylogeny of the three species that includes samples from across Ecuador (Figure 7, which is a simplified version of Elmer et al. 2007b Figure 2). We designate P. kichwarum as two subclades: the more diverse Napo clade that includes the type locality, and the Cuyabeno clade that is found in the north of Ecuador, which is drawn separately to reflect its higher intraspecific divergence relative to the rest of the clade (discussed above).

There has been extensive discussion about what level of genetic diversity may represent new candidate species of amphibians (see Moritz and Cicero 2004, Vences et al. 2005, and references therein). In these three new species, there is no overlap between intra- and inter-specific $p$-distances: a maximum threshold of $7 \%$ divergence at cytochrome $b$ and $4 \%$ divergence at $16 \mathrm{~S}$ is sufficient to demarcate intraspecific diversity, while interspecific diversity exceeds $11 \%$ for cytochrome $b$ and $4 \%$ for $16 \mathrm{~S}$. Therefore, the mtDNA genetic diversity within and between these neotropical Pristimantis are comparable to levels as also found in some other terrestrial tropical frogs at similar geographic scales (see Vences et al. 2004, Vences et al. 2005, Fouquet et al. 2007).

\section{Taxonomy}

The new species described here-P. achuar, P. altamnis, and P. kichwarum-are not ockendeni, though they have been known by this specific epithet in Ecuador since 1974. Genetic data evidenced here and in Elmer et al. (2007b) clearly distinguishes these three species, and these data enabled detection of subtle but consistent morphological differences among the species.

The three species are also quite different from type specimens of possible nominal species to which they might have been assigned. Having reviewed the original description of Hylodes ockendeni (Boulenger $1912 \mathrm{p}$. 667) and photographs of a syntype (BM 1947.2.16.89, adult female, SVL = 31.42), we are confident that the three species we describe here are not $P$. ockendeni. First, one of the most distinguishing features of $P$. altamnis, $P$. kichwarum, and P. achuar relative to other frogs in the area is the presence of an occipital W-shaped ridge. However, this key feature is not mentioned in the description of Hylodes ockendeni Boulenger 1912 (based on three specimens) and is absent in the syntype we reviewed. Second, the size of the holotype and syntype specimens ( 34 and $31 \mathrm{~mm} \mathrm{SVL}$, respectively), is larger than the species we describe here. Third, photographs demonstrate notable morphological differences between P. ockendeni and the species described here, for example: the snout is shorter, the canthus rostalis less sharp in cross-section, the finger discs larger, and the venter more pale in P. ockendeni. Fourth, and perhaps most obviously, Boulenger's specimens come from La Union, Carabaya, a locality in extreme southeastern Peru approximately $1500 \mathrm{~km}$ from our Ecuadorean localities. Given the limited geographical ranges of most Andean and Amazonian amphibians (Lynch \& Duellman 1997; Lougheed et al. 1999; Wynn \& Heyer 2001; Graham et al. 2004), it is very unlikely that any of the new species would be the same species as one from southern Peru.

Given that we have described three new species, it is important to rule out the possibility that these might be referable to species synonymized under P. ockendeni. Two nominal taxa are relevant: Syrrhophus calcaratus Andersson 1945, and Hylodes hylaeformis Melin 1941. 
Syrrhophus calcaratus was described from the Rio Cosanga, $800 \mathrm{~m}$ altitude in Napo province, Ecuador (Andersson 1945). Without examining specimens, Lynch (1968) transferred it to the genus Eleutherodactylus as part of a set of nomenclatural actions designed to revise the genus Syrrhophus. Because the name calcaratus was occupied by Eleutherodactylus calcaratus Boulenger 1908, Lynch (1968) provided the replacement name Eleutherodactylus anderssoni. Later, Lynch (1974) synonymized E. anderssoni with E. ockendeni based on similar morphology between the two species.

After reviewing holotype photographs (NRM 1921), the original species description (Andersson $1945 \mathrm{p}$. 27-28), and the description in Lynch (1974), we are confident that none of the three species described here is E. anderssoni. First, though there is a W-shaped occipital marking in the E. anderssoni holotype, it is clearly not an elevated ridge nor is the notable character of a $\mathrm{W}$-shaped ridge mentioned in the species description (Andersson 1945). In fact, the first mention of the occipital W-shaped ridge is by Lynch (1974), who associated this mark with specimens described as morph B of ockendeni, while morph A (like the types of Hylodes ockendeni and Syrrhophus calcaratus) lacks the ridge. Second, the implication of Andersson's placement of the new species he described into the genus Syrrhophus was that it lacked vomerine teeth, a feature then considered to define Syrrhophus. Lynch (1974) noted that the vomerine odontophores were concealed in the holotype of $S$. calcaratus. The species we describe here have obviously exposed vomerine odontophores, as well as vomerine teeth. Third, there are notable morphological differences between the holotype of $S$. calcaratus and the new species (Figure 8); for example, the tip of the snout is more pointed in S. calcaratus, the snout is shorter, and the canthus rostralis less defined than the species we describe here; the limbs are shorter and plumper, and the head is narrower in S. calcaratus; ventral colouration is paler than P. kichwarum or P. altamnis.

In 1941 Melin described Hylodes hylaeformis from Roque in the Department of San Martín in northern Peru. Bokermann (1958) proposed E. melini as a replacement name because E. hylaeformis was preoccupied. Lynch (1980) synonymized Hylodes hylaeformis (and by implication E. melini) under E. ockendeni. However, he did not examine any material of the species, and simply noted that "in the absence of differences, E. melini (and H. hylaeformis) is added to the synonymy of E. ockendeni" (page 12).

Lynch (1980) examined more than 350 specimens of what he called E. ockendeni from Colombia, southern Ecuador, and northern Peru (including San Martín), many part of the Harvey Bassler collections at the American Museum of Natural History. Clearly his concept of E. ockendeni was a broader one than that supported by the evidence presented in this paper. Like Lynch, we also did not examine any material of E. melini. Given the geographic pattern of genetic divergence observed among the three species described herein, and the geographic distance between our new species and the type locality of E. melini in the Department of San Martín, it is unlikely that any of the species described here are referable to E. melini. Although we have no direct evidence, it is also unlikely that E. melini is conspecific with the type material of E. ockendeni.

Lynch (1980) noted that samples of E. ockendeni collected from southern Amazonian Ecuador are notably smaller than those from northern Ecuador. We found that although $P$. altamnis and P. kichwarum are almost identical in size, $P$. achuar are significantly smaller than $P$. altamnis or $P$. kichwarum (t-test, $P<0.001$ ) (Table 3). Based on geographic location (Cuisime in Morona-Santiago province is approximately $100 \mathrm{~km} \mathrm{WSW}$ from Kapawi [Figure 5 locality 13]) and their snout-vent length (23.4 mm females, $17.3 \mathrm{~mm}$ males), we expect that Malkin's ockendeni from Cuisime (Lynch 1980) are actually $P$. achuar (though it is unclear from the text whether the Malkin specimens are morph A, morph B, or a mixture).

In recent years herpetologists in Ecuador have considered the species $P$. ockendeni to be typified as only morph $\mathrm{B}$, i.e., having a W-shaped black occipital ridge. For example, the entire collection of $P$. ockendeni (excluding some misidentifications) in Ecuador's largest museum collection, QCAZ, have the W-shaped ridge; morph A was thought not to exist in Ecuador (pers. comm. L.A. Coloma). When this change in concept of "ockendeni" in Ecuador-from morph A to exclusively morph B-occurred is unclear but to our eye the photograph of E. ockendeni in Duellman (1978) is not the same frog that has come to be known as P. ocken- 
deni, so this shift presumably happened in the last 20 years. Pristimantis achuar, P. altamnis, and P. kichwarum surely taxonomically replace " $P$. ockendeni morph B" in Ecuador and their description clarifies some taxonomic uncertainty about leaflitter Pristimantis in Ecuador and the dissonance about P. ockendeni morphs. We have not examined all available material of $P$. "ockendeni" so the status of some records are unclear and confusion remains about the species-level status and definition of $P$. "ockendeni" morph A in Ecuador, Peru, and elsewhere.

TABLE 3. Snout-vent lengths of female and male "E. ockendeni" as previously published (Lynch 1980) and compared to current measurements for P. altamnis, P. kichwarum and P. achuar across Ecuador.

\begin{tabular}{lll}
\hline & females & males \\
\hline "E. ockendeni" from northern Ecuador $^{\mathrm{a}}$ & $27.2 \pm 0.5(\mathrm{n}=37)$ & $19.4 \pm 0.5(\mathrm{n}=18)$ \\
P. altamnis $^{\mathrm{b}}$ & $25.5 \pm 3.1(\mathrm{n}=15)$ & $18.5 \pm 1.5(\mathrm{n}=60)$ \\
P. kichwarum $^{\mathrm{b}}$ & $25.3 \pm 2.9(\mathrm{n}=32)$ & $18.8 \pm 1.6(\mathrm{n}=74)$ \\
"E. ockendeni" from southern Ecuador (Malkin) $^{\mathrm{a}}$ & $23.4 \pm 0.3(\mathrm{n}=18)$ & $17.3 \pm 1.0(\mathrm{n}=4)$ \\
P. achuar $^{\mathrm{b}}$ & $21.8 \pm 1.4(\mathrm{n}=8)$ & $15.5 \pm 0.7(\mathrm{n}=10)$ \\
\hline
\end{tabular}

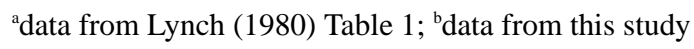

We can summarize our taxonomic decisions as follows: Pristimantis ockendeni is not conspecific with any of the new species, nor is it likely to be found in Ecuador, given its type locality. "Eleutherodactylus" anderssoni is a species distinct from any of the species described herein; it is also distinct from P. ockendeni. It is poorly characterized, however, and its distribution unknown except for the type locality. Although we have no direct evidence, by extrapolation from what we know about the new species described herein, it is likely that E. melini from northern Peru is also distinct from P. ockendeni, as well as from the Ecuadorean species we describe here.

Given Lynch's (1974) description of two morphs and the common difficulty of distinguishing Pristimantis species, we encourage researchers to (1) provide more details about the morphological characters (canthal stripe, etc.) used to assign specimens to species that are similar to P. "ockendeni," (2) photograph a variety of morphs in life, and (3) collect vouchered tissue samples for deposition in institutional collections. Clearly, in the case of $P$. ockendeni in Ecuador, a "species" that was presumed to be well-known, a sample of toe clips without voucher specimens would have been worthless.

Pristimantis in Ecuador are speciose and often difficult to distinguish and therefore are not as well-studied as more colourful or sonorous frogs. However, of the Pristimantis, the species referred to P. ockendeni are relatively common in many Ecuadorean forests and has been studied previously (e.g., articles mentioned above, as well as: Lynch \& Duellman 1980; Izquierdo et al. 2000; Cisneros-Heredia 2003; Coloma 2005; CisnerosHeredia 2006; Elmer et al. 2006). Given our revised taxonomy, the single locality studies of "E. ockendeni" in Elmer et al. (2006) and (2007a) are P. kichwarum. The Upland, Lowland, and Southeastern "E. ockendeni" clades of Elmer et al. (2007b) are P. altamnis, P. kichwarum, and P. achuar respectively. The species identified as "E. ockendeni" in studies from elsewhere in the upper Amazon are unlikely the same species as the three described here (e.g., Heyer \& Berven 1973; Toft \& Duellman 1979; Toft 1980; Aichinger 1987; Duellman \& Salas 1991; Rodríguez \& Duellman 1994; Duellman \& Mendelson 1995; Duellman \& Thomas 1996; Zimmerman \& Simberloff 1996; Duellman \& Pramuk 1999; Acosta-Galvis 2000; Doan \& Arizábal Arriaga 2002; Padial et al. 2004; Heinicke et al. 2007; Lehr et al. 2007). Duellman (2005) reported one specimen of P. ockendeni from Cusco Amazónico. His description is very general and matches all of the leaflitter Pristimantis described herein from Ecuador. The photo included (plate 83) is of a specimen from northern Peru, Loreto. Geographically, this frog would most likely be $P$. achuar. 


\section{Conclusion}

The morphological conservatism among these three new species-P. achuar, $P$. altamnis, and $P$. kichwarum -is striking. In fact, without the genetic analyses to demonstrate high divergence among clades it is unlikely they would have been recognized as distinct species rather than geographic variants or polymorphic populations. However, with detailed a posteriori revision of specimens we were able to identify minor but reliable morphological differences by which the three new species can be discerned based on morphology alone, even in absence of geographical or genetic information. Other recent genetic studies have demonstrated that many neotropical amphibian taxa are composed of highly divergent lineages and cryptic species (e.g., Chek et al. 2001; Crawford 2003; Camargo et al. 2006; Ron et al. 2006; Crawford et al. 2007; Fouquet et al. 2007). Thus, the diversity of amphibians in the upper Amazon of Ecuador is certainly much greater than current estimates and our incomplete catalogues.

\section{Specimens examined}

Pristimantis achuar [10 specimens]

ECUADOR: Orellana: Bloque Shiripuno, QCAZ 9555, 9572; Yasuní carreterra Pomeya Sur-Iro km 38, QCAZ 8101, 8112; Yasuní pozo Capiron 2, QCAZ 17331. Pastaza: Kapawi Lodge, QCAZ 11189; Lorocachi, QCAZ 10006; Loc. Petrolera Garza 1, NE of Montalvo, QCAZ 1213, 1217, 1221.

\section{Pristimantis altamnis [146 specimens]}

ECUADOR: Napo: Jatun Sacha Biological Station, QCAZ 2887, 18116, 18127, 18130, 18147, 18148, 18150152, 18154, 18167, 25439, 25440-442, 25445-447, 25553, 25556, 25557, 25559, 25560, 25562, 25563, 25574, 25578; Llanganates Mtns, Canton Arosamena Tola, QCAZ 25327, 25328; Talag, QCAZ 4516; Sta Rita, QCAZ 7024. Pastaza: Y of road Tena to Puyo, Canton Sta Clara, QCAZ 25334, 25337, 25338, $25342-$ 345, 25348-353, 25356-359, 25361, 25362, 25364, 25366, 25372, 25374, 25377, 25378, 25381, 25383; Fundación Hola Vida, El Porvenir, QCAZ 25164, 25165, 25601, 25654, 25655, 25658-664, 25692-700, 25742. Orellana: Rio Huataraco, via Hollín-Loreto, QCAZ 7084. Sucumbíos: community Chonta Yacu, via Lumbaqui-Tulcan, QCAZ 25786, 25796, 25804-25813, 25819-25838. Zamora-Chinchipe: Centro Shuar Yawi, QCAZ 31031.

\section{Pristimantis kichwarum [388 specimens]}

ECUADOR: Napo: Jatun Sacha Biological Station and adjacent Arajuno Jungle Lodge, QCAZ 2888, 91829214, 18021, 18022, 18024-026, 18028, 18029, 18031, 18032, 18034-18038, 18040, 18042-044, 18046-052, 18054-068, 18070, 18072-076, 18078-084, 18086-088, 18090, 18091, 18093-095, 18097, 18099-109, 18111, 18113-115, 18118-125, 18129, 18131, 18133-136, 18138, 18140-146, 18149, 18155, 18164, 18166, 25292, 25293, 25299, 25440-442, 25446, 25553, 25555-557, 25559, 25560, 25562, 25563, 25574, 25578, 25754756, 25760-765, 25767, 25770, 25772, 25775, 25776, 25778-781; Puca Chicta, east of Misahuallí, QCAZ 18156, 18157; Serena, south side Rio Napo, QCAZ 25839-847, 25854-860, 25863, 26864, 25866-25870, 25873. Orellana: Parque Nacional Yasuní, Onkonogare, QCAZ 5103, 5208, 6916, 6955, 6958; Estación Científica Yasuní, QCAZ 7928-931, 7933, 7934, 7964, 8449, 8450, 11659, 13100, 16638, 16640, 16641, 16647, 16655, 16761, 19208, 19221, 19330, 19332, 20846, 20847, 20849-853, 23843, 24305, 25154; Parque Nacional Yasuní, AMO 1, km 96-98, QCAZ 5330, 5349, 5359, 5369, 5382, 5431, 6556; Parque Nacional Yasuní, road to MAXUS km 107, QCAZ 6915, 6919-921, 6923, 6924, 6927-929, 6942-954, 6956, 6959-963, 6966; Parque Nacional Yasuní, Pomeya Sur-Iro Road km 38-41, QCAZ 8086, 8091, 8099, 8100, 8102, 8105, 8114, 8119, 8128, 9336, 9350, 17332, 17334, 17349, 17355, 17356, 17359, 17363, 17368, 17370, 20139; Parque Nacional Yasuní, pozo Capiron 2, QCAZ 9347, 17333; Parque Nacional Yasuní, Bloque Shiripuno, QCAZ 9550, 9552; Parque Nacional Yasuní, Bloque 31, QCAZ 11872-878; Parque Nacional Yasuní (general), QCAZ 5078, 5090, 5092, 5093, 5095, 5104, 5137, 5142, 5152, 5156, 5163, 5164, 5203, 5205, 5328, 
5329, 5342, 5343, 5346, 5456, 5457, 5465, 5466, 5468, 5469, 6694-696, 6913, 8174, 8938, 9006, 9338, 9349, 9689, 10150, 10576-578, 10580, 11867, 12073, 12074, 12076, 12077, 13302, 14890-899, 15083, 17366, 20484, 22265, 22460, 24292; Rio Huataraco, via Hollín-Loreto, QCAZ 7085, 7087-090; Yuturi, QCAZ, 10417; Auca 14 Road south of Dayuma, QCAZ 25277, 25599; Comuna El Descanso, QCAZ 12547; Indillama, $15 \mathrm{~km}$ east Pompeya, QCAZ 4652-655, 5016, 11440. Pastaza: Bataburo Lodge, Rio Tiguño, QCAZ 20037, 20067. Sucumbios: La Selva Lodge, Pañacocha, QCAZ 4375, 8514-516, 25429.

Pristimantis sp. ("Pristimantis ockendeni" not re-assigned) [26 specimens]

ECUADOR: Sucumbíos: Zábalo, QCAZ 27826, 27831, 27833, 27938, 27985, 28019, 28021, 28026, 28030, 28032, 28048, 28049, 28058, 28140; Puerto Bolivar, QCAZ 28183, 28195; Rey de los Andes (Rio Cuyabeno at road), QCAZ 27873, 28087; PUCE station, Lag. Cuyabeno, QCAZ 25576, 25577. Orellana: Parque Nacional Yasuní, QCAZ 8101, 8112, 17331, 17343, 17575, 19208.

\section{Acknowledgments}

Many thanks to F. Ayala Varela, T. Sugahara, I.G. Tapia, M. Orozco, W. Poveda, E. "Gato" Jimenez, G. Tapuy, P. Menéndez-Guererro, S. Padilla, M. Bustamante, G. Vigle, and P. Grefa for assistance in the field, and to the QCAZ collaborators who have collected "ockendeni" over the years. Jatun Sacha Biological Station, Arajuno Jungle Lodge, P. Grefa, Comunidad Chonta Yacu, Cabañas Lidia, M. Tapia, La Selva Jungle Lodge, Kapawi Jungle Lodge, Municipio de Arosamena Tola, M. Foley, M. Terry, and D. Duncan provided lodging and support in the field. J. Kim and T. Sugahara assisted with sexing some specimens. J. Padial and E. Åhlander provided type photos.Thanks to V. Swain and G. Gallagher-Mackay for improving photographs in life, D. Cisneros-Heredia for proof-reading, and S.Mann for the foundations of Figure 5. KRE samples were collected with permits 006-IC-FAU-DBAP/MA, 016-IC-FAU-DNBAP/MA, and 010-IC-FAU-DFP from Ministerio del Ambiente, Ecuador and permission of the Federación Interprovincial de Nacionalidad Achuar del Ecuador. We acknowledge AmphibiaTree (National Science Foundation, USA) for funding. The manuscript was improved with comments by E. Lehr.

\section{References}

Acosta-Galvis, A.R. (2000) Ranas, salamandras, y caecilias (Tetrapoda: Amphibia) de Colombia. Biota Colombiana, 1, 289-319.

Aichinger, M. (1987) Annual activity patterns of anurans in a seasonal neotropical environment. Oecologia, 71, 583592.

Andersson, L.G. (1945) Batrachians From East Ecuador Collected 1937, 1938 By Wm. Clarke-Macintyre and Rolf Blomberg. Kongliga Svenska Vetenskaps-Akademiens Stockholm, 1-88 pp.

Bokermann, Werner C. A. (1958) A preoccupied name of a neotropical frog, genus Eleutherodactylus. Herpetologica, $14,95$.

Boulenger, G.A. (1912) Descriptions of new Batrachians from the Andes of South America, preserved in the British Museum. Annals and Magazine of Natural History, ser 8, X, 185-191.

Camargo, A., de Sá, R.O. \& Heyer, W.R. (2006) Phylogenetic analyses of mtDNA sequences reveal three cryptic lineages in the widespread neotropical frog Leptodactylus fuscus (Schneider, 1799) (Anura, Leptodactylidae). Biological Journal of the Linnean Society, 87, 325-341.

Cisneros-Heredia, D.F. (2003). Herpetofauna de la Estación de Biodiversidad Tiputini, Amazonía Ecuatoriana: Ecología de una comunidad taxonómicamente diversa con comentarios sobre methodologías de inventario. In S. De la Torre, \& G. Reck (Eds.), (CD). Quito, Ecuador: Universidad San Francisco de Quito.

Cisneros-Heredia, D.F. (2005) Amphibia, Epipedobates bilinguis, Agalychnis calcarifer, Eleutherodactylus croceoinguinis: Distribution extensions. Check List, 1, 14-15.

Cisneros-Heredia, D.F. (2006) Notes on Geographic Distribution: Amphibia, Brachycephalidae, Eleutherodactylus skyd- 
mainos: First country record, Ecuador. Check List, 2, 47-49.

Chek, A.A., Lougheed, S.C., Bogart, J.P. \& Boag, P.T. (2001) Perception and history: molecular phylogeny of a diverse group of neotropical frogs, the 30-chromosome Hyla (Anura: Hylidae). Molecular Phylogenetics and Evolution, 18, 370-85.

Coloma, L.A. (ed) (2005-2007) Anfibios de Ecuador [en linea]. Ver. 2.0 (29 Oct. 2005). Museo de Zoologia, Pontificia Universidad Catolica del Ecuador Quito, Ecuador. <www.puce.edu.ec/zoologia/vertebrados/amphibiawebec/anfibiosecuador/index.html>.

Crawford, A.J. (2003) Huge populations and old species of Costa Rican and Panamanian dirt frogs inferred from mitochondrial and nuclear gene sequences. Molecular Ecology, 12, 2525-2540.

Crawford A.J., Bermingham E. \& Polanía S.C. (2007) The role of tropical dry forest as a long-term barrier to dispersal: a comparative phylogeographical analysis of dry forest tolerant and intolerant frogs. Molecular Ecology, 16, 47894807.

Doan, T.M. \& Arizábal Arriaga, W. (2002) Microgeographic variation in species composition of the herpetofaunal communities of Tambopata region, Peru. Biotropica, 34, 101-117.

Duellman, W.E. (1978) The Biology of an Equatorial Herpetofauna in Amazonian Ecuador. University of Kansas Lawrence, Kansas, USA, 1-352.

Duellman, W.E. (2005) Cusco Amazónico. The lives of amphibians and reptiles in an Amazonian rainforest. Cornell University Press.

Duellman, W.E. \& Lynch, J.D. (1988). Anuran amphibians from the cordillera de Cutucú. Proceedings of the Academy of Natural Sciences of Philadelphia, 140, 125-142.

Duellman, W.E. \& Mendelson III, J.R. (1995) Amphibians and reptiles from northern Departamento Loreto, Peru: taxonomy and biogeography. University of Kansas Science Bulletin, 55, 329-376.

Duellman, W.E. \& Pramuk, J.B. (1999) Frogs of the genus Eleutherodactylus (Anura: Leptodactylidae) in the Andes of northern Peru. Natural History Museum of the University of Kansas, Miscellaneous Publication, 13, 1-78.

Duellman, W.E. \& Salas, A.W. (1991) Annotated checklist of the amphibians and reptiles of Cuzco Amazonica, Peru. Occasional Papers of the Museum of Natural History, Univ. of Kansas, 143, 1-13.

Duellman, W.E. \& Thomas, R. (1996) Anuran amphibians from a seasonally dry forest in southeastern Peru and comparison of the anurans among sites in the upper Amazon basin. Occasional Papers of the Natural History Museum University of Kansas, 180, 1-34.

Elmer, K.R. (2004) Geographic distribution. Eleutherodactylus librarius. Herpetological Review, 35, 77.

Elmer, K.R., Dávila, J.A. \& Lougheed, S.C. (2006) Isolation of simple and compound polymorphic tetranucleotide microsatellites for the neotropical leaflitter frog Eleutherodactylus ockendeni (Leptodactylidae). Molecular Ecology Notes, 6, 891-893.

Elmer, K.R., Dávila, J.A. \& Lougheed, S.C. (2007a) Applying new inter-individual approaches to assess fine-scale population genetic diversity in a neotropical frog, Eleutherodactylus ockendeni. Heredity, 99, 506-515.

Elmer, K.R., Dávila, J.A. \& Lougheed, S.C. (2007b) Cryptic diversity and deep divergence in an upper Amazonian leaflitter frog, Eleutherodactylus ockendeni. BMC Evolutionary Biology, 7, 247.

Flores, G. \& Vigle, G.O. (1994) A new species of Eleutherodactylus (Anura: Leptodactylidae) from the lowland rainforests of Amazonian Ecuador, with notes on the Eleutherodactylus frater assembly. Journal of Herpetology, 28, 416424.

Fouquet, A., Vences, M., Salducci, M.-D., Meyer, A., Marty, C., Blanc, M. \& Gilles, A. (2007) Revealing cryptic diversity using molecular phylogenetics and phylogeography in frogs of the Scinax ruber and Rhinella margaritifer species groups. Molecular Phylogenetics and Evolution, 43, 567-582.

Graham, C.H., Ron, S.R., Santos, J.C., Schneider, C.J. \& Moritz, C. (2004) Integrating phylogenetics and environmental niche models to explore speciation mechanisms in dendrobatid frogs. Evolution, 58, 1792-1793.

Guayasamín, J.M., Ron, S.R., Cisneros-Heredia, D.F., Lamar, W. \& McCracken, S.F. (2006) A new species of frog of the Eleutherodactylus lacrimosus assemblage (Leptodactylidae) from the western Amazon basin, with comments on the utility of canopy surveys in lowland rainforest. Herpetologica, 62, 191-202.

Hedges, S. B., Duellman, W. E. \& Heinicke, M.P. (2008) New World direct-developing frogs (Anura: Terrarana): molecular phylogeny, classification, biogeography, and conservation. Zootaxa, 1737, 1-182.

Heinicke, M.P., Duellman, W.E. \& Hedges, S.B. (2007) Major Caribbean and Central American frog faunas originated by ancient oceanic dispersal. Proceedings of the National Academy of Sciences of the United States of America, 104, 10092-10097.

Heyer, W.R. (1988) On frog distribution patterns east of the Andes. In: Heyer, W.R. \& P.E. Vanzolini (Eds.). Proceedings of a Workshop on Neotropical Distribution Patterns. Acad. Brasil. Cien. Rio de Janeiro, Brazil, pp. 245-273.

Heyer, W.R. \& Berven, K.A. (1973) Species diversities of herpetofaunal samples from similar microhabitats at two tropical sites. Ecology, 54, 642-645.

IUCN, Conservation International \& NatureServe. (2006). Global Amphibian Assessment. <www.globalamphibians.org>Izquierdo, J., Nogales, F. \& Yánez, A.P. (2000) Análisis herpetofaunístico de un bosque húmedo tropical en 
la Amazonía Ecuatoriana. Ecotrópicos, 13, 29-42.

Lehr, E., Torres, C. \& Suárez, J. (2007) A new species of arboreal Eleutherodactylus (Anura: Leptodactylidae) from the Amazonian lowlands of central Peru. Herpetologica, 63, 94-99.

Lougheed, S.C., Gascon, C., Jones, D.A., Bogart, J.P. \& Boag, P.T. (1999) Ridges and rivers: a test of competing hypotheses of Amazonian diversification using a dart-poison frog (Epipedobates femoralis). Proceedings of the Royal Society of London. Series B, 266, 1829-1835.

Lynch, J.D. (1968) Systematic status of some Andean leptodactylid frogs with a description of a new species of Eleutherodactylus. Herpetologica, 24, 289-300.

Lynch, J.D. (1974) New species of frogs (Leptodactylidae: Eleutherodactylus) from the Amazonian lowlands of Ecuador. Occasional Papers of the Museum of Natural History Kansas, 31, 1-22.

Lynch, J.D. (1980) A taxonomic and distributional synopsis of the Amazonian frogs of the genus Eleutherodactylus. American Museum Novitates, 2696, 1-24.

Lynch, J. D. \& Duellman, W. E. (1980) The Eleutherodactylus of the Amazonian slopes of the Ecuadorian Andes (Anura: Leptodactylidae). Miscellaneous Publications of the Natural History Museum, University of Kansas, 69, 186.

Lynch, J.D. \& Duellman, W.E. (1997) Frogs of the genus Eleutherodactylus (Leptodactylidae) in western Ecuador: systematics, ecology, and biogeography. Miscellaneous Publications of the Natural History Museum, University of Kansas, 23, 1-236.

Maddison, D.R. \& Maddison, W.P. (2003) MacClade 4: Analysis of Phylogeny and Character Evolution. Version 4.07. Sinauer Associates, Sunderland, USA.

Moritz C. \& Cicero C. (2004) DNA Barcoding: Promise and Pitfalls. PLoS Biology, 2, e354.

Padial, J.M., Gonzáles, L., Reichle, S., Aguayo, R. \& de la Riva, I. (2004) First records of five species of the genus Eleutherodactylus Duméril and Bibron, 1841 (Anura, Leptodactylidae) for Bolivia. Graellsia, 60, 167-174.

Pearman, P.B. (1997) Correlates of amphibian diversity in an altered landscape in Amazonian Ecuador. Conservation Biology, 11, 1211-1225.

Posada, D (1998-2006) Collapse: Describing Haplotypes From Sequence Alignments Ver. 1.2. <http://darwin.uvigo.es/ software/collapse.html>.

Rodríguez, L.O. \& Duellman, W.D. (1994) Guide to Frogs of the Iquitos Region, Amazonian Peru. University of Kansas Museum of Natural History Special Publication No. 22 Kansas, USA, 1-80 pp.

Ron, S.R., Santos, J.C. \& Cannatella, D.C. (2006) Phylogeny of the tungara frog genus Engystomops (=Physalaemus pustulosus species group; Anura: Leptodactylidae). Molecular Phylogenetics and Evolution, 39, $392-403$.

Swofford, D.L. (2003) PAUP*. Phylogenetic Analysis Using Parsimony (*and Other Methods). Version 4. Sinauer Associates, Sunderland, USA.

Toft, C.A. (1980) Feeding ecology of thirteen syntopic species of anurans in a seasonal tropical environment. Oecologia, $45,131-141$.

Toft, C.A. \& Duellman, W.E. (1979) Anurans of the lower Rio Llulapichis, Amazonian Peru: a preliminary analysis of community structure. Herpetologica, 35, 71-77

Vences, M., Thomas, M., van der Meijden, A., Chiari, Y. \& Vietes, D. R. (2004). Comparative performance of the 16S rRNA gene in DNA barcoding of amphibians. Frontiers in Zoology, 2, 5.

Vences M., Thomas M., Bonett R.M. \& Vieites D.R. (2005) Deciphering amphibian diversity through DNA barcoding: chances and challenges. Philosophical Transactions of the Royal Society of London. Series B, 360, 1859-1868.

Wynn, A. \& Heyer, W.R. (2001) Do geographically widespread species of tropical amphibians exist? An estimate of genetic relatedness within the neotropical frog Leptodactylus fuscus (Schneider 1799) (Anura Leptodactylidae). Tropical Zoology, 14, 255-285.

Zimmerman, B.L. \& Simberloff, D. (1996) An historical interpretation of habitat use by frogs in a Central Amazonian forest. Journal of Biogeography, 23, 27-46. 

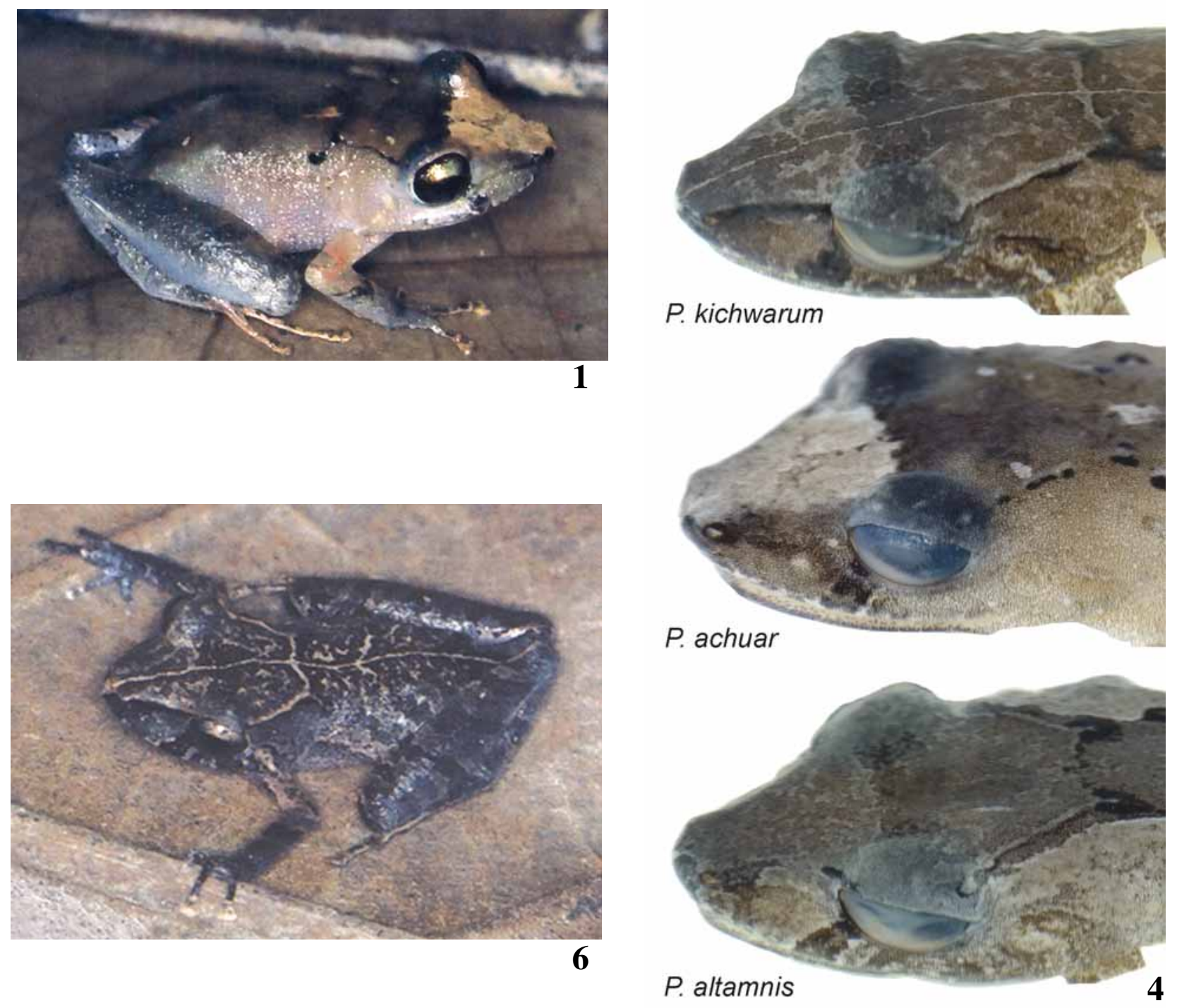

FIGURE 1. Photograph of $P$. achuar holotype (QCAZ 25463) in life.

FIGURE 4. Lateral view of specimens of P. kichwarum (QCAZ 18033), P. achuar (QCAZ 25463), and P. altamnis (QCAZ 25311). Note the presence of a canthal stripe and darkened supratympanic ridge in P. kichwarum and their absence in P. achuar and P. altamnis.

FIGURE 6. Eleutherodactylus kichwarum holotype (QCAZ 18128) in life. 

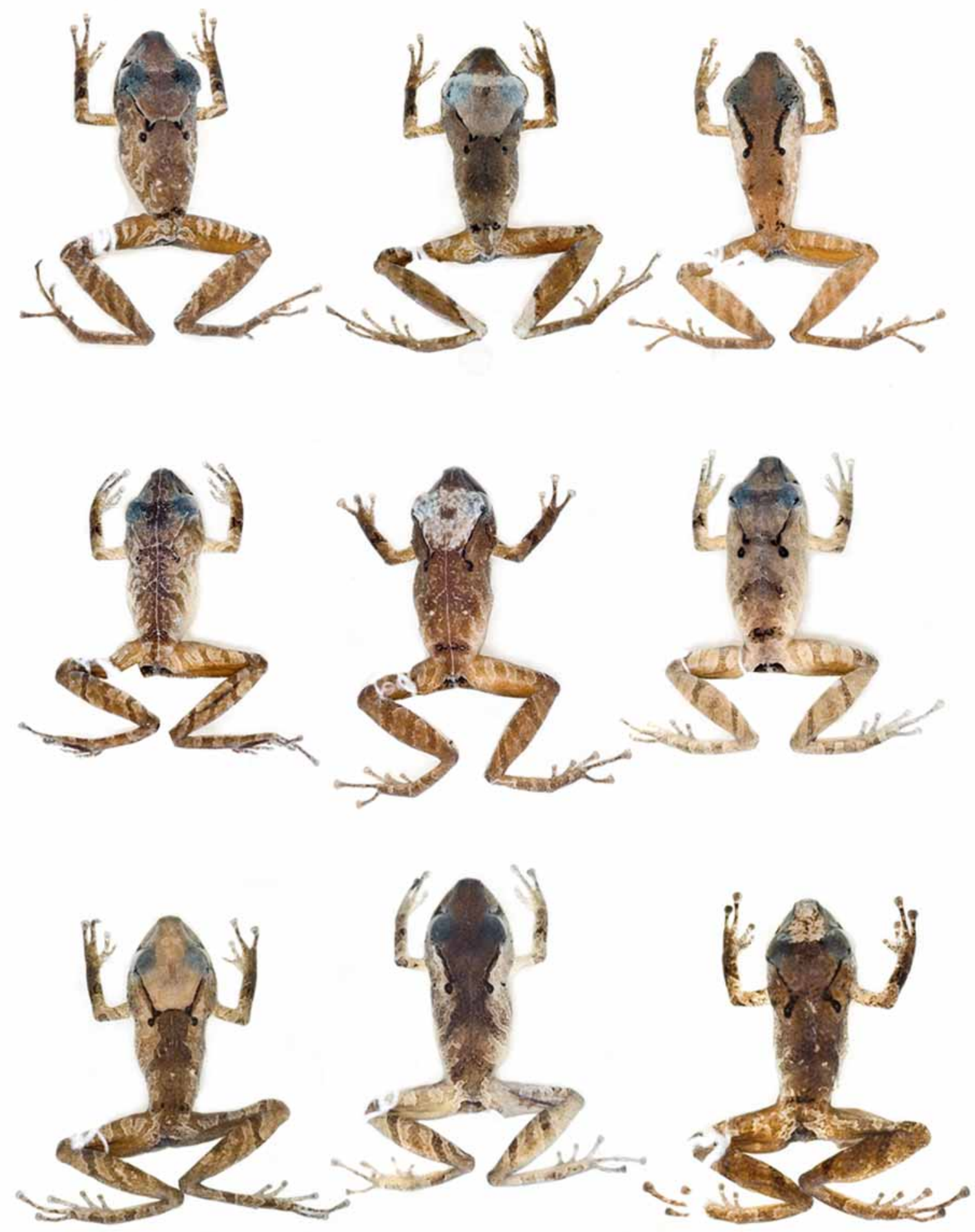

FIGURE 2. Dorsal view of three paratypes of $P$. altamnis (top row; QCAZ 25313, 25302, 25304), P. kichwarum (middle row; QCAZ 25287, 27762, 25782), and P. achuar (bottom row; QCAZ 25538, 25490, 25491). Note the presence of a canthal stripe in P. kichwarum and its absence in P. altamnis and P. achuar. 

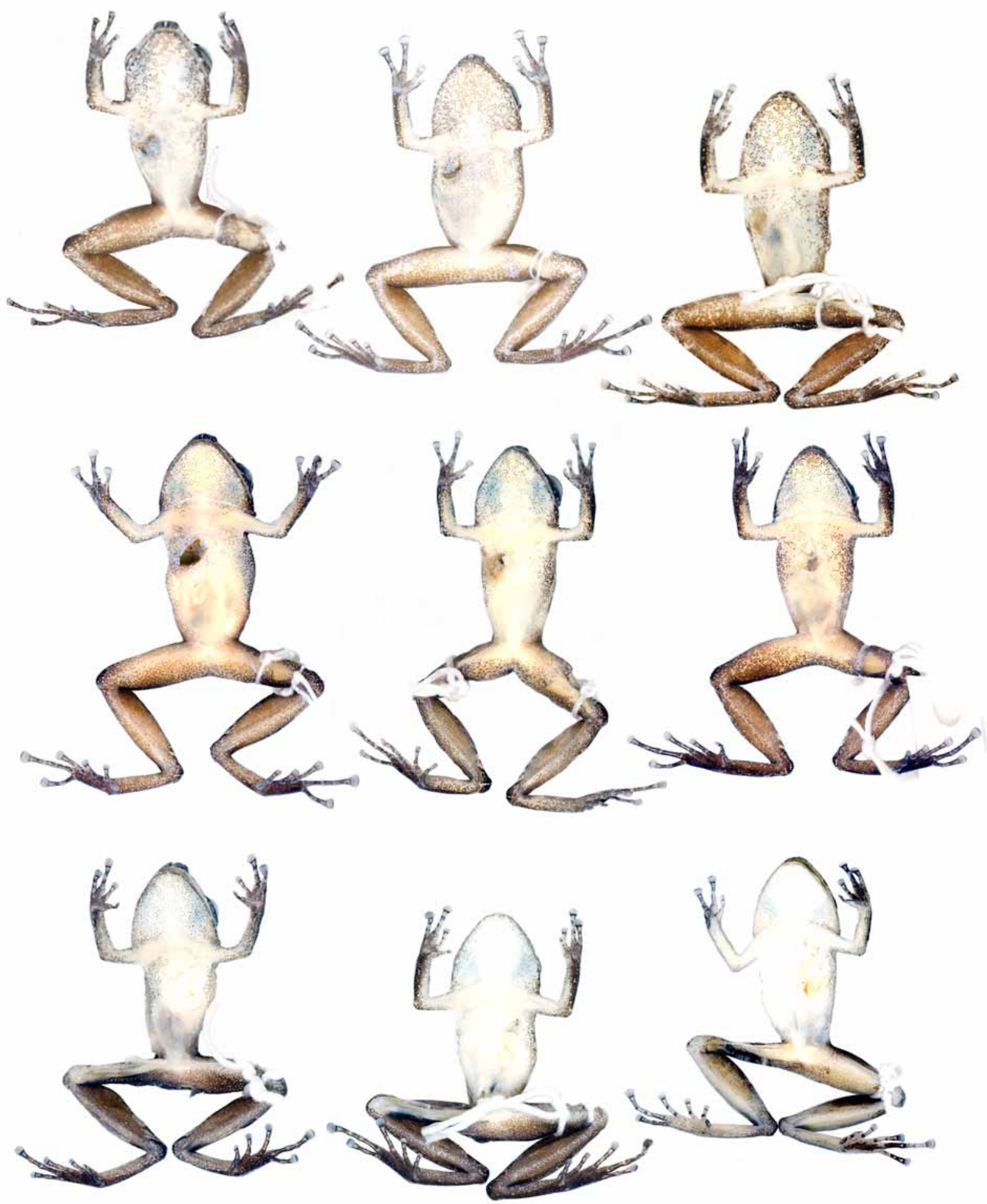

FIGURE 3. Ventral view of three paratypes of $P$. altamnis (top row; QCAZ 25445, 25442, 25447), P. kichwarum (middle row; QCAZ 25287, 25558, 25759), and P. achuar (bottom row; QCAZ 25461, 25530, 25534). Note the difference in ventral colouration between the three species, with $P$. altamnis having the most dense flecking of melanophores and $P$. achuar having the palest venter. 


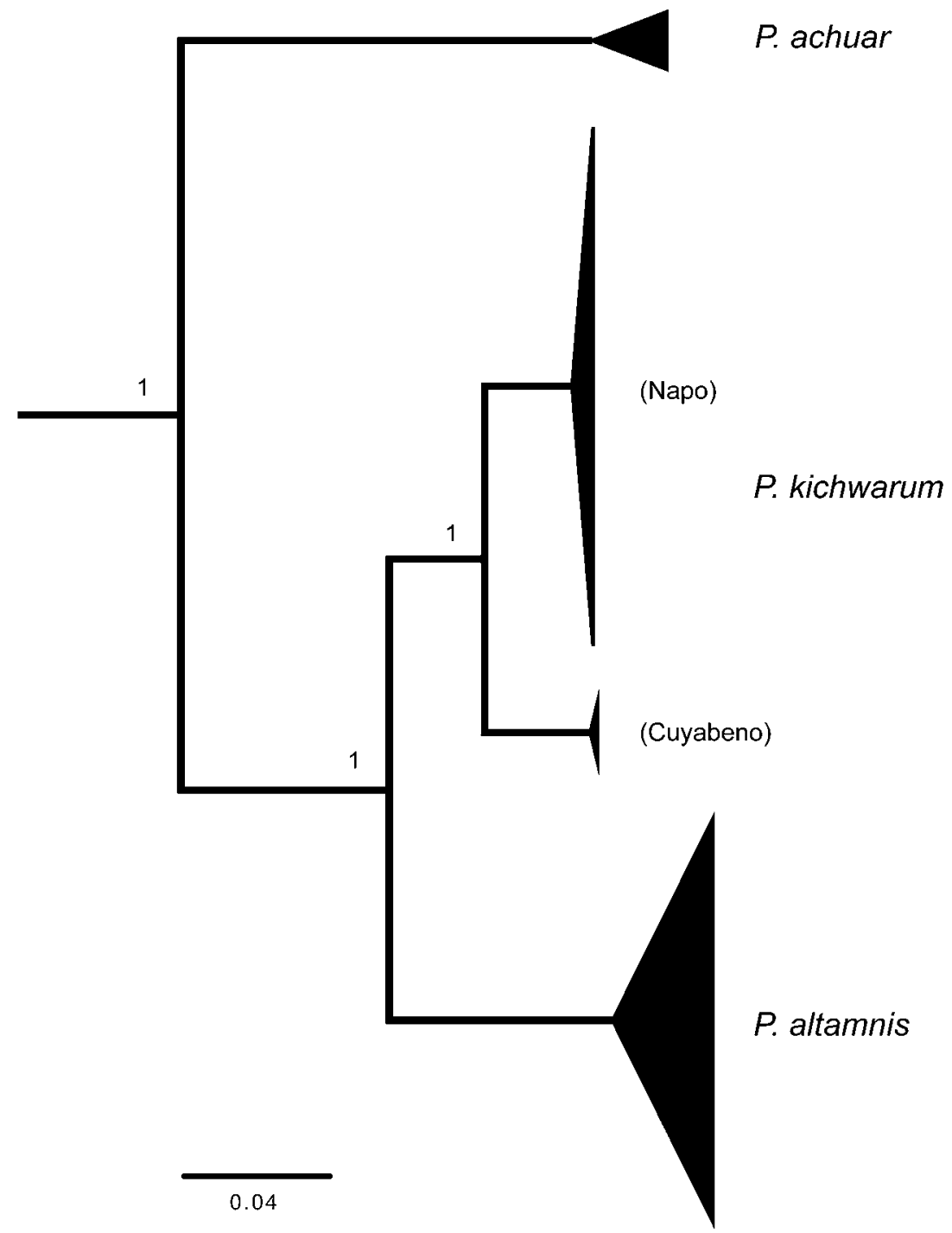

FIGURE 7. Bayesian phylogenetic tree of $P$. achuar, $P$. altamnis, and $P$. kichwarum based on mtDNA cytochrome $b$ and 16S. Posterior probabilities are labelled at nodes. Two subclades are noted within P. kichwarum. The size of terminal triangles reflect the amount of diversity when samples from across the range are included (from Elmer et al. 2007b).
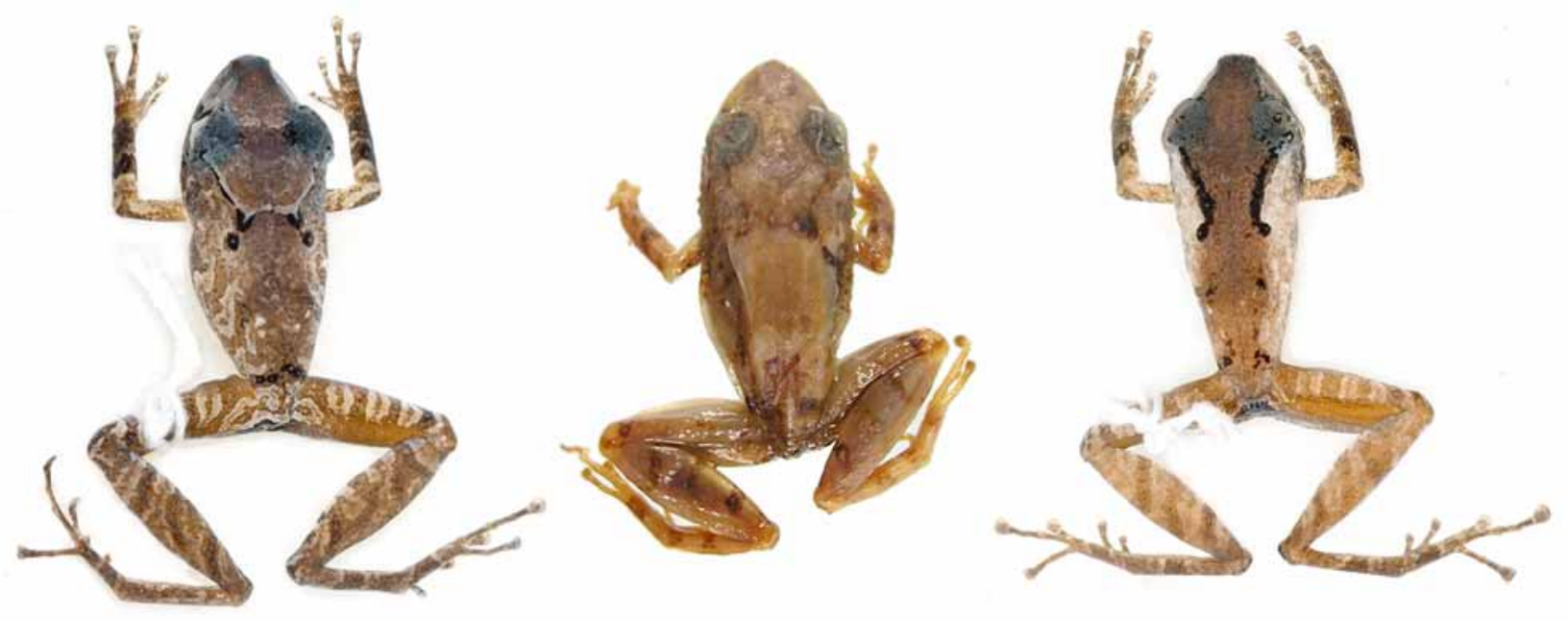

FIGURE 8. Dorsal view of two specimens of P. altamnis (left and right; QCAZ 25313 and 25304) and the holotype of S. calcaratus (centre; NRM 1921). Note the lack of a darkened W-shaped occipital ridge, the pointed snout, different colour patterning, and shorter, plumper hindlimbs of $S$. calcaratus compared to P. altamnis. 
Appendix 1. Paratypes of Pristimantis kichwarum with museum catalogue number, field number, locality, date of collection, collectors, and Genbank accession numbers for mtDNA cytochrome $b$ and 16S [with acceptance]. EBJS = Jatun Sacha Biological Station, parroquia Ahuano, Canton Tena, Provincia Napo, Ecuador; FAV = F. Ayala-Varela; TS = T. Sugahara. Samples used for measurement and colour diagnosis in the species description are marked with an asterix.

\begin{tabular}{|c|c|c|c|c|c|c|c|c|c|}
\hline $\begin{array}{l}\text { Museum } \\
\text { QCAZ \# }\end{array}$ & $\begin{array}{l}\text { Field } \\
\text { Number }\end{array}$ & $\begin{array}{l}\text { Local- } \\
\text { ity }\end{array}$ & $\begin{array}{c}\text { Alti- } \\
\text { tude } \\
(\mathbf{m})\end{array}$ & Latitude & Longitude & Sex & $\begin{array}{c}\text { Date of Collec- } \\
\text { tion (dd-mm- } \\
\text { yyyy) }\end{array}$ & Field Collectors & $\begin{array}{l}\text { Genbank accession } \\
\text { no. }(\text { cyt b/ 16S) }\end{array}$ \\
\hline 18023 & SC7625 & EBJS & 461 & $\mathrm{~S}^{2} 1^{\circ} 04.057$ & W77 37.008 & male & $04-11-2001$ & KRE, FAV & /EU130581 \\
\hline 18027 & SC7639 & EBJS & 448 & $\mathrm{~S} 01^{\circ} 04.070$ & W77º36.980 & female & 04-11-2001 & KRE, FAV & EF581014/ \\
\hline 18030 & SC7654 & EBJS & 456 & $\mathrm{~S} 01^{\circ} 04.214$ & W77³6.989 & male & $05-11-2001$ & KRE, FAV & EF581015/ \\
\hline 18033 & SC7657 & EBJS & 452 & $\mathrm{~S}_{01}^{\circ} 04.204$ & W77³6.949 & female & 05-11-2001 & KRE, FAV & EF581016/ \\
\hline 18039 & SC7663 & EBJS & 449 & $\mathrm{~S} 01^{\circ} 04.122$ & W77º37.159 & male & $05-11-2001$ & KRE, FAV & EF581017/ \\
\hline 18041 & SC7667 & EBJS & 456 & $\mathrm{~S} 01^{\circ} 04.209$ & W77 37.003 & male & $05-11-2001$ & KRE, FAV & EF581018/ \\
\hline 18045 & SC7673 & EBJS & 451 & $\mathrm{~S} 01^{\circ} 04.092$ & W77 37.142 & male & 05-11-2001 & KRE, FAV & EF581019/ \\
\hline 18053 & SC7686 & EBJS & 463 & $\mathrm{~S} 01^{\circ} 04.062$ & W77º37.091 & female & 06-11-2001 & KRE, FAV & EF581020/ \\
\hline 18069 & SC7706 & EBJS & 420 & $\mathrm{~S} 01^{\circ} 04.110$ & $\mathrm{~W} 77^{\circ} 36.887$ & male & 08-11-2001 & KRE, FAV & $\begin{array}{l}\text { EF581021/ } \\
\text { EU130582 }\end{array}$ \\
\hline 18071 & SC7708 & EBJS & 439 & $\mathrm{~S} 01^{\circ} 04.195$ & $\mathrm{~W} 77^{\circ} 36.863$ & male & 08-11-2001 & KRE, FAV & EF581022/ \\
\hline 18077 & SC7717 & EBJS & 440 & $\mathrm{~S} 01^{\circ} 04.229$ & $\mathrm{~W} 77^{\circ} 36.840$ & male & $09-11-2001$ & KRE, FAV & EF581023/ \\
\hline 18085 & SC7725 & EBJS & 414 & $\mathrm{~S} 01^{\circ} 04.286$ & W77 36.834 & male & 09-11-2001 & KRE, FAV & EF581024/ \\
\hline 18089 & SC7741 & EBJS & 423 & $\mathrm{~S} 01^{\circ} 04.420$ & W77 36.698 & male & $11-11-2001$ & KRE, FAV & EF581025/ \\
\hline 18092 & SC7744 & EBJS & 418 & $\mathrm{~S} 01^{\circ} 04.339$ & $\mathrm{~W} 77^{\circ} 36.787$ & male & $11-11-2001$ & KRE, FAV & EF581026/ \\
\hline 18096 & SC7748 & EBJS & 416 & $\mathrm{~S} 01^{\circ} 04.425$ & $\mathrm{~W} 77^{\circ} 36.685$ & male & $11-11-2001$ & KRE, FAV & EF581027/ \\
\hline 18098 & SC7750 & EBJS & 419 & $\mathrm{~S} 01^{\circ} 04.326$ & W77 $7^{\circ} 36.814$ & male & $11-11-2001$ & KRE, FAV & EF581028/ \\
\hline 18110 & SC7762 & EBJS & 423 & $\mathrm{~S} 01^{\circ} 04.054$ & $\mathrm{~W} 77^{\circ} 37.008$ & female & $12-11-2001$ & KRE, FAV & EF581029/ \\
\hline 18112 & SC7766 & EBJS & 415 & $\mathrm{~S} 01^{\circ} 04.254$ & W77º36.896 & male & $13-11-2001$ & KRE, FAV & EF581030/ \\
\hline $18117^{*}$ & SC7771 & EBJS & $\mathrm{n} / \mathrm{a}$ & $\mathrm{n} / \mathrm{a}$ & $\mathrm{n} / \mathrm{a}$ & female & $13-11-2001$ & KRE, FAV & EF581031/ \\
\hline 18126 & SC7781 & EBJS & 419 & $\mathrm{~S} 01^{\circ} 04.460$ & W77º36.795 & female & $14-11-2001$ & KRE, FAV & EF581032/ \\
\hline $18132^{*}$ & SC7790 & EBJS & 419 & $\mathrm{~S} 01^{\circ} 04.520$ & $\mathrm{~W} 77^{\circ} 36.650$ & female & $16-11-2001$ & KRE, FAV & $\begin{array}{l}\text { EF581034/ } \\
\text { EU130583 }\end{array}$ \\
\hline 18137 & SC7795 & EBJS & 371 & $\mathrm{~S} 01^{\circ} 04.463$ & $\mathrm{~W} 77^{\circ} 36.678$ & male & $16-11-2001$ & KRE, FAV & EF581035/ \\
\hline 18139 & SC7798 & EBJS & 424 & $\mathrm{~S} 01^{\circ} 04.788$ & W77 36.787 & male & $19-11-2001$ & KRE, FAV & EF581036/ \\
\hline $18153^{*}$ & SC7822 & EBJS & 432 & $\mathrm{~S} 01^{\circ} 04.705$ & $\mathrm{~W} 77^{\circ} 36.595$ & female & $30-11-2001$ & KRE, FAV & EF581037 \\
\hline 18165 & SC7595 & EBJS & 399 & $\mathrm{~S} 01^{\circ} 03.895$ & W77º37.029 & male & 02-11-2001 & KRE, FAV & EF581013/ \\
\hline 25287 & SC11099 & $\begin{array}{l}\text { EBJS } \\
\text { (Inner } \\
\text { Vision } \\
\text { Lodge) }\end{array}$ & 408 & $\mathrm{~S} 01^{\circ} 06.113$ & $\mathrm{~W} 77^{\circ} 35.582$ & female & 09-04-2003 & KRE, TS & EF581048/ \\
\hline $25288^{*}$ & SC11100 & $\begin{array}{l}\text { EBJS } \\
\text { (Inner } \\
\text { Vision } \\
\text { Lodge) }\end{array}$ & 408 & $\mathrm{~S} 01^{\circ} 06.113$ & $\mathrm{~W} 77^{\circ} 35.582$ & male & 09-04-2003 & KRE, TS & EF581049/ \\
\hline $25290^{*}$ & SC11102 & $\begin{array}{l}\text { EBJS } \\
\text { (Inner } \\
\text { Vision } \\
\text { Lodge) }\end{array}$ & 433 & $\mathrm{~S} 01^{\circ} 06.091$ & $\mathrm{~W} 77^{\circ} 35.648$ & male & 09-04-2003 & KRE, TS & EF581051/ \\
\hline $25291^{*}$ & SC11103 & $\begin{array}{l}\text { EBJS } \\
\text { (Inner } \\
\text { Vision } \\
\text { Lodge) }\end{array}$ & 396 & $\mathrm{~S} 01^{\circ} 06.116$ & W77º35.594 & male & 09-04-2003 & KRE, TS & EF581050/ \\
\hline 25295 & SC11107 & $\begin{array}{l}\text { EBJS } \\
\text { (Inner } \\
\text { Vision } \\
\text { Lodge) }\end{array}$ & 396 & $\mathrm{~S} 01^{\circ} 06.110$ & $\mathrm{~W} 77^{\circ} 35.590$ & $\begin{array}{c}\text { juve- } \\
\text { nile }\end{array}$ & 09-04-2003 & KRE, TS & $\begin{array}{l}\text { EF581052/ } \\
\text { EU130595 }\end{array}$ \\
\hline $25552^{*}$ & SC11010 & $\begin{array}{l}\text { EBJS } \\
\text { (Librar } \\
\text { ius } \\
\text { Study } \\
\text { Cen- } \\
\text { ter) }\end{array}$ & 383 & $\mathrm{~S} 01^{\circ} 03.619$ & $\mathrm{~W} 77^{\circ} 36.923$ & male & $20-02-2003$ & KRE & EF581039/ \\
\hline $25554^{*}$ & SC11007 & $\begin{array}{c}\text { EBJS } \\
\text { (Librar } \\
\text { ius } \\
\text { Study } \\
\text { Cen- } \\
\text { ter) }\end{array}$ & 390 & $\mathrm{~S} 01^{\circ} 03.700$ & W77³6.962 & female & $20-02-2003$ & KRE & EF581040/ \\
\hline
\end{tabular}




\begin{tabular}{|c|c|c|c|c|c|c|c|c|c|}
\hline $25555^{*}$ & SC11001 & $\begin{array}{l}\text { EBJS } \\
\text { (Librar } \\
\text { ius } \\
\text { Study } \\
\text { Cen- } \\
\text { ter) }\end{array}$ & 390 & $\mathrm{~S} 01^{\circ} 03.754$ & W77 36.882 & male & $20-02-2003$ & KRE & EF581038/ \\
\hline 25558 & SC11009 & $\begin{array}{l}\text { EBJS } \\
\text { (Librar } \\
\text { ius } \\
\text { Study } \\
\text { Cen- } \\
\text { ter) }\end{array}$ & 384 & $\mathrm{~S} 01^{\circ} 03.627$ & W77 36.937 & male & $20-02-2003$ & KRE & EF581041/ \\
\hline 25561 & SC11006 & $\begin{array}{l}\text { EBJS } \\
\text { (Librar } \\
\text { ius } \\
\text { Study } \\
\text { Cen- } \\
\text { ter) }\end{array}$ & 392 & $\mathrm{~S} 01^{\circ} 03.661$ & W77 36.927 & $\begin{array}{l}\text { juve- } \\
\text { nile }\end{array}$ & $20-02-2003$ & KRE & EF581042/ \\
\hline 25564 & SC11013 & $\begin{array}{l}\text { EBJS } \\
\text { (Librar } \\
\text { ius } \\
\text { Study } \\
\text { Cen- } \\
\text { ter) }\end{array}$ & 404 & $\mathrm{~S} 01^{\circ} 03.839$ & W77 36.879 & male & 21-02-2003 & KRE & EF581043/ \\
\hline 25573 & SC11022 & $\begin{array}{l}\text { EBJS } \\
\text { (Librar } \\
\text { ius } \\
\text { Study } \\
\text { Cen- } \\
\text { ter) }\end{array}$ & 400 & $\mathrm{~S} 01^{\circ} 03.841$ & W77³6.866 & male & $22-02-2003$ & KRE & EF581044/ \\
\hline $25575^{*}$ & SC11024 & $\begin{array}{l}\text { EBJS } \\
\text { (Librar } \\
\text { ius } \\
\text { Study } \\
\text { Cen- } \\
\text { ter) }\end{array}$ & 405 & $\mathrm{~S} 01^{\circ} 03.825$ & W77 36.861 & female & $22-02-2003$ & KRE & $\begin{array}{c}\text { EF581045 } \\
/\end{array}$ \\
\hline 25579 & SC11027 & $\begin{array}{l}\text { EBJS } \\
\text { (Librar } \\
\text { ius } \\
\text { Study } \\
\text { Cen- } \\
\text { ter) }\end{array}$ & 390 & $\mathrm{~S} 01^{\circ} 03.740$ & W77º36.879 & $\begin{array}{l}\text { juve- } \\
\text { nile }\end{array}$ & 13-03-2003 & KRE & $\begin{array}{l}\text { EF581046/ } \\
\text { EU130592 }\end{array}$ \\
\hline $25580^{*}$ & SC11029 & $\begin{array}{l}\text { EBJS } \\
\text { (prop- } \\
\text { erty of } \\
\text { Don } \\
\text { Gab- } \\
\text { riel) }\end{array}$ & 404 & $\mathrm{~S}_{0} 1^{\circ} 04.102$ & W77³6.694 & male & $16-03-2003$ & KRE & $\begin{array}{c}\text { EF581047 } \\
/\end{array}$ \\
\hline $25751^{*}$ & SC11125 & $\begin{array}{l}\text { EBJS } \\
\text { (Inner } \\
\text { Vision } \\
\text { Lodge) }\end{array}$ & 398 & $\mathrm{~S} 01^{\circ} 06.110$ & $\mathrm{~W} 77^{\circ} 35.850$ & female & $13-04-2003$ & KRE, TS & $\underset{/}{\text { EF581055 }}$ \\
\hline $25757^{*}$ & SC11122 & $\begin{array}{l}\text { EBJS } \\
\text { (Inner } \\
\text { Vision } \\
\text { Lodge) }\end{array}$ & 419 & $\mathrm{~S} 01^{\circ} 06.049$ & W77 35.067 & male & $13-04-2003$ & KRE, TS & $\begin{array}{c}\text { EF581054 } \\
/\end{array}$ \\
\hline 25759 & SC11118 & $\begin{array}{c}\text { EBJS } \\
\text { (Inner } \\
\text { Vision } \\
\text { Lodge) }\end{array}$ & 398 & $\mathrm{~S} 01^{\circ} 06.110$ & $\begin{array}{c}\text { W77635.85 } \\
6\end{array}$ & male & $13-04-2003$ & KRE, TS & $\begin{array}{l}\text { EF581053/ } \\
\text { EU130596 }\end{array}$ \\
\hline 25773 & SC11145 & $\begin{array}{c}\text { EBJS } \\
\text { (Inner } \\
\text { Vision } \\
\text { Lodge) }\end{array}$ & 413 & $\mathrm{~S} 01^{\circ} 05.720$ & $\mathrm{~W} 77^{\circ} 35.901$ & male & $16-04-2003$ & KRE, TS & $\begin{array}{c}\text { EF581060 } \\
/\end{array}$ \\
\hline 25782 & SC11154 & $\begin{array}{c}\text { EBJS } \\
\text { (Inner } \\
\text { Vision } \\
\text { Lodge) }\end{array}$ & 416 & $\mathrm{~S} 01^{\circ} 06.225$ & W77 35.662 & female & $17-04-2003$ & KRE, TS & $\begin{array}{c}\text { EF581062 } \\
/\end{array}$ \\
\hline
\end{tabular}

